NBER WORKING PAPER SERIES

PARENTAL EMPLOYMENT AND

CHILD COGNITIVE DEVELOPMENT

\author{
Christopher J. Ruhm \\ Working Paper 7666 \\ http://www.nber.org/papers/w7666 \\ NATIONAL BUREAU OF ECONOMIC RESEARCH \\ 1050 Massachusetts Avenue \\ Cambridge, MA 02138 \\ April 2000
}

I thank Carey Borkoski for research assistance and Li Gan, Hilary Hoynes, Shelly Lundberg, Dan Rosenbaum, Donna Ruane Morrison, Steven Stern, David Wildesin and seminar participants at Georgetown University, the University of California at Berkeley, University of Kentucky, University of Texas, University of Virginia, and Vanderbilt University for helpful comments. Financial support from the University of North Carolina Greensboro and the National Science Foundation (SES-9876511) is gratefully acknowledged. The views expressed herein are those of the author and are not necessarily those of the National Bureau of Economic Research.

(C) 2000 by Christopher J. Ruhm. All rights reserved. Short sections of text, not to exceed two paragraphs, may be quoted without explicit permission provided that full credit, including (C) notice, is given to the source. 
Parental Employment and Child Cognitive Development

Christopher J. Ruhm

NBER Working Paper No. 7666

April 2000

JEL No. I12, J13, J18, J22

\begin{abstract}
$\underline{\text { ABSTRACT }}$
This study investigates the relationship between parental employment and child cognitive development using data from multiple years of the National Longitudinal Survey of Youth. Maternal labor supply during the first three years of the child's life is predicted to have a small negative effect on the verbal ability of 3 and 4 year olds and a substantial detrimental impact on the reading and math achievement of 5 and 6 year olds. Working during the second and third years appears to have less favorable or more deleterious consequences when the mother is also employed in the first year. The results are robust to the inclusion of controls for day care arrangements or paternal job-holding and there is some indication that early employment may be particularly costly for children in "traditional" two-parent families. Finally, the data suggest that paternal and maternal employment have qualitatively similar effects, hinting at the importance of time investments by fathers. The overall conclusion is that previous research may have provided an overly optimistic assessment of the effects of parental employment on child cognitive development.
\end{abstract}

\author{
Christopher J. Ruhm \\ Department of Economics \\ University of North Carolina at Greensboro \\ P.O. Box 26165 \\ Greensboro, NC 27402-6165 \\ and NBER \\ c_ruhm@uncg.edu
}




\section{Parental Employment and Child Cognitive Development}

The first three years of life are increasingly recognized as a critical period for children (e.g. Carnegie Task Force on Meeting the Needs of Young Children, 1994; Council of Economic Advisers, 1997). Recent research emphasizes the long-lasting effects of early environmental influences on brain development (Shore, 1997), and environmental factors could also be significant for the development of learning skills, self-esteem and emotional security. ${ }^{1}$ Time investments of parents during the first years may therefore promote healthy development.

In 1980, 44 percent of single and 45 percent of married females with children under the age of 6 participated in the labor force. By 1996, participation had increased to 55 and 63 percent. $^{2}$ Over the same period, the fraction of children raised in single parent households rose from 20 to 28 percent (U.S. Department of Commerce, 1997). These changes suggest that parents have less time to invest in children, with potentially deleterious effects. ${ }^{3}$ However, increased employment may also yield benefits, most obviously by providing extra income.

This paper analyzes the relationship between parental employment and child cognitive development. Data are from multiple years of the National Longitudinal Survey of Youth (NLSY). The dependent variables are scores on three high quality assessments of cognitive skill. Despite considerable prior investigation, the effects of parental labor supply remain uncertain. One reason is that it is difficult to adequately control for characteristics that simultaneously affect employment decisions, the home environment, and the quality of time investments. To

\footnotetext{
${ }^{1}$ Heckman (1999) stresses the importance of human capital investments in early childhood, focusing on the role of dynamic complementarities whereby early skill development fosters subsequent learning.

${ }^{2}$ The growth has been even more rapid for mothers with very young children. In the 1994/5 period, 56 percent of mothers with a one year old child participated in the labor force (Klerman \& Leibowitz, 1998). ${ }^{3}$ Increased female employment has not been offset by substantial reductions in male work hours; however, the time women spend in housework has declined substantially since the 1960s, potentially raising that available for children (Juster \& Stafford, 1991; Mayer, 1997). According to a recent estimate by the Council of Economic Advisers (1999), the time parents could potentially spend with children declined by 22 hours per week (or 14 percent) between 1969 and 1999. One obvious question is whether employment translates into less actual time with children. Hofferth's (1999) analysis of time-diary data from the 1997 Child Development Supplement to the Panel Study of Income Dynamics indicates that employed mothers devote less time to their children (aged 12 and under) than their counterparts without jobs and that work hours are negatively correlated with parental involvement for both employed mothers and fathers. However, nonworking fathers spend less time with children than their employed peers. This last issue receives attention in the analysis of paternal employment below.
} 
remedy these shortcomings, this study uses a larger and more representative sample than most previous research, a particularly comprehensive set of explanatory variables, and analyzes a wider set of outcomes and age range of children. The effects of maternal work are also more carefully modeled and job-holding by fathers receives some attention.

The empirical results suggest that maternal employment during the early years has negative effects on child cognitive development. Working during the child's first year is associated with reductions in the verbal ability of 3 and 4 year olds that are partially (but not completely) offset by increases related to employment during the second and third years. Jobholding by mothers results in considerably larger decreases in the expected reading and mathematics achievement scores of 5 and 6 year olds, with particularly pronounced declines associated with employment during the second and third year of the child's life. For all three cognitive outcomes, the effects of employment in the second and third years appear more deleterious (or less favorable) when mothers also hold jobs during the first year. Finally, the data hint that paternal and maternal employment affect child cognitive development in similar ways, suggesting that time investments by fathers are also important. One implication of these findings is that prior research, by failing to adequately control for the heterogeneity between working and nonworking parents and focusing on a narrow age range of children, may have provided an overly optimistic assessment of the effects of parental employment.

\section{A. Previous Research}

The impact of maternal employment on child cognitive development has been widely studied. Much of the research focuses on common outcomes and age groups, most frequently scores of 3 and 4 year olds on the Peabody Picture Vocabulary Test (PPVT), and analyzes data from the NLSY. As detailed in Table 1, some investigations find positive effects (Vandell \& Ramanan, 1992; Parcel \& Menaghan, 1994), others uncover negative impacts (Leibowitz, 1977; Stafford, 1987; Mott 1991), and many obtain differing findings depending on the timing of the employment or specific group analyzed (Desai et al., 1989; Baydar \& Brooks-Gunn, 1991; Blau 
\& Grossberg, 1992; Parcel \& Menaghan, 1994; James-Burdumy, 1998). ${ }^{4}$ The only previous study of paternal employment (Parcel \& Menaghan, 1994), also obtains inconclusive results. ${ }^{5}$

A careful reading of this literature suggests that overall impact of maternal job-holding during the first three years is fairly small, with deleterious effects during the first year offset by benefits for working during the second and third. The patterns may vary with factors such as sex of the child or family income but these differences are not well understood. Mothers with observable characteristics associated with high ability (e.g. education levels, AFQT scores) tend to have relatively elevated employment rates, but selection based on less easily observable factors is poorly identified.

These inferences should be viewed as tentative because the samples have typically been small and unrepresentative, and the outcomes and age groups studied quite limited. Most importantly, mothers who work when their children are young may differ from those who do not in ways that have not been fully accounted for. For example, Vandell \& Ramanan (1992) show that job-holding is more common for women with high levels of education and cognitive skill. If working mothers also have high ability in home activities, employment is likely to be positively associated with child outcomes, even absent a causal impact. Conversely, a spurious negative correlation occurs if women returning to work quickly are more "career" oriented and have less interest or ability in home production. One way to reduce or eliminate the potential bias due to unobserved heterogeneity is to include a comprehensive set of explanatory variables. The results may be difficult to interpret, however, if endogenous regressors such as controls for the home environment are included, since they could absorb a portion of the effect of employment. ${ }^{6}$

\footnotetext{
${ }^{4}$ A related line of inquiry examines whether early child care harms child-mother attachment relationships (e.g. Belsky \& Rovine, 1988; Clarke-Stewart, 1989; Lamb \& Sternberg, 1990; NICHD Early Child Care Research Network, 1997b). The somewhat ambiguous results of this research suggests that maternal employment, by increasing the use of day care, could reduce the security of infant-mother attachments in some situations. However, the size and pattern of the effect is uncertain and none of the studies use nationally representative samples or contains sufficient controls for parental abilities or attitudes.

${ }^{5}$ Parcel and Menaghan's study contains several potential shortcomings. Most importantly, the reference group includes both fathers working 35-40 hours per week and those with missing values (either because they are not present in the household or because work hours are not reported).

${ }^{6}$ There are similar difficulties in interpreting results of the related literature on day care (e.g. ClarkeStewart, 1991; Field, 1991; Caughy et al., 1994). NICHD Early Child Research Network (1997a) shows
} 


\section{B. Conceptual Framework}

Economic models portray households as productive entities where parents allocate resources to maximize an objective function that includes the health and development of children as one of its arguments. Holding marital status and household size constant, more time and income will therefore be devoted to children as more of each is available to the parents. ${ }^{7}$ The psychological and sociological literatures emphasize other, generally complementary, pathways through which parental employment may affect children. Belsky (1988) argues that a mother's absence during the first year of life could disrupt mother-child attachment relationships and deprive the child of the stimulation that promotes cognitive development. Hoffman (1980) states that the stress of maternal employment may yield fewer and lower quality interactions. Coleman (1988) expresses concern that the job-holding will weaken the "social capital" that depends on the relationships in which children are embedded.

The effects of parental employment may also vary with household characteristics and age of the child. If well-off parents provide higher quality time, for instance, employment could be more harmful in rich than poor families (Vandell \& Ramanan, 1992). However, wealthier families can afford better day care and educated women spend a greater proportion of their time at home in child-related activities (Leibowitz, 1974b), possibly reversing this pattern. ${ }^{8}$

that the age at which children are placed in non-parental care varies significantly with maternal and family characteristics. For instance, those beginning child care prior to 3 months of age come from families with relatively low non-maternal incomes whereas those placed in care at 3-5 months of age have the highest family incomes and maternal earnings. Norberg (1998) indicates that mothers of infants with relatively high development scores or more difficult temperaments begin work relatively soon after giving birth. A few studies use quasi-experimental designs to control for omitted variables (e.g., Currie \& Thomas, 1995). See Karoly et al. (1998) for an in-depth review of research examining early intervention programs. The available evidence suggests more uniformly beneficial impacts of job-holding by mothers of older children, particularly for daughters where role model effects of maternal employment appear important (Haveman \& Wolfe, 1995; Blau, et al., 1998).

${ }^{7}$ Leibowitz (1974a) provides an early example of work highlighting the role of time investments in children. There is wide agreement that children benefit from being in households with higher incomes but debate over the nature of the relationship. Duncan \& Brooks-Gunn (1997) emphasize the causal effect of poverty, whereas Mayer (1997) suggests weaker income effects, possibly because a greater portion of family income is devoted to children in poor than wealthy families (Lazear \& Michael, 1988). All else equal, more time will also be invested in children with few siblings and in two-parent (versus single-parent) households (Haveman \& Wolfe, 1995; McLanahan, 1997).

${ }^{8}$ The average quality of child care increases with income, although center-based care for low-income children appears to be of relatively high quality (NICHD Early Child Care Research Network, 1997a). 
All of the aforementioned approaches stress the beneficial effects of household income and parental time, suggesting a potential tradeoff between the two. To illustrate, consider a production function where child outcomes depend on previous status $\left(\mathrm{C}_{\mathrm{t}-1}\right)$, the non-market "leisure" time of parents (L), purchased inputs like food or medical care (F), and exogenous determinants or production shocks (V) according to:

$$
\mathrm{C}_{\mathrm{t}}=\mathrm{C}\left(\mathrm{C}_{\mathrm{t}-1}, \mathrm{~L}_{\mathrm{t}}, \mathrm{F}_{\mathrm{t}}, \mathrm{V}_{\mathrm{t}}\right){ }^{9}
$$

Using subscripts to indicate partial derivatives, $\mathrm{C}_{\mathrm{L}}$ and $\mathrm{C}_{\mathrm{F}}$ are positive. The production function has several important characteristics. First, parental time is assumed to be good for children. This occurs either through direct time investments or indirectly through reductions in stress, increased energy levels, and so forth. Second, higher incomes raise the ability of parents to purchase productive inputs and influence their time allocation decisions. ${ }^{10}$ Third, child outcomes depend partly on prior status and therefore on the past choices of parents.

Parents have a time constraint

$$
\mathrm{L}_{\mathrm{t}}+\mathrm{H}_{\mathrm{t}}=1 \text {, }
$$

where $\mathrm{H}(\mathrm{L})$ is the proportion of time spent in employment (leisure) activities, and a budget constraint that limits purchases of child inputs and other consumption by the amount of earned and nonearned income. ${ }^{11}$ Solving (2) for $\mathrm{H}$ and recursively substituting in for lagged values of $\mathrm{C}$, equation (1) can be rewritten as:

$$
\mathrm{C}_{\mathrm{t}}=\mathrm{C}\left(\mathbf{H}_{\mathrm{t}}, \mathbf{F}_{\mathrm{t}}, \mathbf{V}_{\mathrm{t}}\right) \text {, }
$$

where $\mathbf{H}, \mathbf{F}$, and $\mathbf{V}$ are vectors of current and lagged values (e.g. $\mathbf{H}_{\mathrm{t}}=\left\{\mathrm{H}_{\mathrm{t}}, \mathrm{H}_{\mathrm{t}-1}, \ldots \mathrm{H}_{\mathrm{t}-\mathrm{n}}\right\}$ ), for $\mathrm{t}-\mathrm{n}$ the first period in which parental inputs affect child outcomes). The empirical analysis does not

This is probably due to early intervention programs (such as Head Start) available to poor families. Greenstein (1995) presents evidence suggesting that advantaged children are not disproportionately harmed by maternal employment.

${ }^{9}$ This model follows Becker (1981) in emphasizing the role of non-market time in household production and Grossman (1972) in treating health as an outcome produced by investment activities.

${ }^{10}$ Formally, parents solve a dynamic programming problem where utility depends on child outcomes, parental consumption and non-market time, and is maximized subject to time and budget constraints. Under fairly general conditions, the reduced-form leisure time and child outcome functions vary with wages, prices, non-labor income, and health or utility shocks. Blau et al. (1996) detail such a model. ${ }^{11}$ Total time is actually endogenous since it varies with the number of parents and children in the household. The econometric analysis deals with this by including detailed controls for family structure. 
estimate the structural production function described by (3), but rather focuses on the reducedform model:

$$
\mathrm{C}_{\mathrm{t}}=\mathrm{C}\left(\mathbf{H}_{\mathrm{t}}, \mathbf{X}\right)
$$

where $\mathbf{X}$ is a vector of parental and family background characteristics.

The employment coefficients obtained from equation (4) show the "net" impact of parental job-holding and reflect the (presumably) offsetting effects of increased income and decreased leisure. Ideally, $\mathbf{X}$ accounts for all other factors influencing the structural determinants of child outcomes. For example, the proportion of total income devoted to children could vary with parental and family background characteristics. Similarly, parental attitudes about labor supply could be correlated with other investments in children. ${ }^{12}$ If the supplementary regressors do not adequately control for these factors, the reduced-form estimates may be biased.

A further difficulty is that child outcomes will generally depend on the quality as well as the quantity of parental time investments, and on the "technologies" in place when decisions are made. For instance, since child care is one purchased input, the effects of parental employment are partially a function of the difference in the quality of parental and nonparental care.

Therefore the productivity of non-market time is likely to rise as the (price-adjusted) quality of nonparental day care falls. ${ }^{13}$ A fully specified model would account for the endogeneity between these technologies and parental decisions but the regression estimates below do not. Instead, the employment coefficients indicate the "effects" of working given the average differences in other factors (such as child care) that accompany the variation in labor supply. This procedure is reasonable if the time allocation decision precedes and determines the use of these other inputs. It is less appropriate for considering how parental employment might affect child development in a different institutional environment.

\footnotetext{
${ }^{12}$ In a formal model, these would be reflected by preference or production shifters.

${ }^{13}$ This could be modeled by specifying the child production function as $\mathrm{C}_{\mathrm{t}}=\mathrm{C}\left(\mathrm{C}_{\mathrm{t}-1}, \mathrm{q}_{\mathrm{t}} \mathrm{L}_{\mathrm{t}}, \mathrm{F}_{\mathrm{t}}, \mathrm{V}_{\mathrm{t}}\right)$, where $\mathrm{q}$ is an efficiency parameter translating parental time into child outcomes that partly depends on differences in the quality of parental and nonparental care. Parental time could then have a negative effect $(q<0)$, if its quality is sufficiently low relative to day care.
} 


\section{Econometric Issues}

The reduced-form model in equation (4) can be operationalized by assuming that the cognitive assessment score (C) for child $i$ at age $t$ is a function of observable characteristics (X), parental employment $(\mathrm{H})$ at $\mathrm{t}-\mathrm{j}$, time-invariant unobserved parental characteristics $(\mathrm{M})$, and child-specific endowments $(\mathrm{K})$, according to:

$$
\mathrm{C}_{\mathrm{it}}=\mathrm{a}+\mathrm{X}_{\mathrm{it}} \mathrm{b}+\mathrm{H}_{\mathrm{it}-\mathrm{j}} \mathrm{c}_{\mathrm{t}-\mathrm{j}}+\mathrm{M}_{\mathrm{i}}+\mathrm{K}_{\mathrm{i}}+\mathrm{e}_{\mathrm{it}},
$$

where e is an i.i.d. error term. ${ }^{14}$ The basic econometric model is:

$$
\mathrm{C}_{\mathrm{it}}=\alpha+\mathrm{X}_{\mathrm{it}} \beta+\mathrm{H}_{\mathrm{it}-\mathrm{j}} \gamma+\varepsilon_{\mathrm{it}}
$$

where $\varepsilon_{i t}=M_{i}+K_{i}+e_{i t .}$. The coefficient of primary interest $\hat{\gamma}$ measures the impact of parental employment but will yield biased estimates if $\operatorname{cov}\left(\mathrm{H}_{\mathrm{it}-\mathrm{j}} \varepsilon_{\mathrm{it}}\right) \neq 0$. This occurs if $\mathrm{M}$ or $\mathrm{K}$ are correlated with H. For example, a spurious positive relationship is induced if employed women have relatively high home productivity $\left(\operatorname{cov}\left(\mathrm{H}_{\mathrm{it}-\mathrm{j}} \mathrm{M}_{\mathrm{i}}\right)>0\right)$ or if the children of working mothers have endowments resulting in high levels of cognitive skill $\left(\operatorname{cov}\left(\mathrm{H}_{\mathrm{it}-\mathrm{j}} \mathrm{K}_{\mathrm{i}}\right)>0\right)$.

The primary econometric strategy is to use the detailed information available in the NLSY to directly account for many potential confounding factors. Omitted variables bias will be further reduced by controlling for maternal employment prior to birth or after the third year of life. To show how this is useful, assume that regressions of equation (6) yield $E\left(\hat{\gamma}_{\mathrm{t}-\mathrm{j}}\right)=\mathrm{c}_{\mathrm{t} \cdot \mathrm{j}}+\mathrm{d}+$ $f$, where $d$ is the bias due to the correlation between work hours and a maternal fixed effect and $f$ is that due to the association between employment and unobserved child characteristics. Notice that for period t-p in which parental job-holding has no causal effect, $\mathrm{c}_{\mathrm{t}-\mathrm{p}}=0$ and $\mathrm{E}\left(\hat{\gamma}_{t-p}\right)=\mathrm{d}+\mathrm{f}$. Including $\mathrm{H}_{\mathrm{it-p}}$ in the model will therefore "soak up" much of the unobserved heterogeneity. Therefore, the estimating equations often take the form:

$$
\mathrm{C}_{\mathrm{it}}=\alpha+\mathrm{X}_{\mathrm{it}} \beta+\mathrm{H}_{\mathrm{it}-\mathrm{j}} \gamma+\mathrm{H}_{\mathrm{it}-\mathrm{p}} \delta+\varepsilon_{\mathrm{it}},
$$

where $\mathrm{H}_{\mathrm{t}-\mathrm{j}}$ indicates work in the period of primary interest (the first three years of life) and $\mathrm{H}_{\mathrm{t}-\mathrm{p}}$ refers to labor supply in earlier and later time periods.

Sibling fixed-effect (FE) models are also useful because they are likely to provide an

\footnotetext{
${ }^{14} \mathrm{H}$ is generally a vector indicating parental employment at various child ages.
} 
upper-bound (lower-bound) on the benefits (costs) of maternal employment. To see this, consider the regression equation:

$$
\mathrm{C}_{\mathrm{iqt}}=\alpha+\mathrm{X}_{\mathrm{iqt}} \beta+\mathrm{H}_{\mathrm{iqt}-\mathrm{j}} \gamma+\mathrm{M}_{\mathrm{q}} \delta+\varepsilon_{\mathrm{iqt}},
$$

where $\mathrm{C}_{\mathrm{iqt}}$ indicates the assessment score of child $\mathrm{i}$ with mother $\mathrm{q}$ at age $\mathrm{t}$ and $\mathrm{M}$ is a vector of mother-specific dummy variables that captures the effects of unobserved parental characteristics. The regression error term in (8) is $\varepsilon_{\mathrm{iqt}}=\mathrm{K}_{\mathrm{i}}+\mathrm{e}_{\mathrm{iqt}}$, implying that $\hat{\gamma}$ will be upwards biased if $\operatorname{cov}\left(\mathrm{H}_{\mathrm{iqt}} \mathrm{K}_{\mathrm{i}}\right)>0$, as seems likely. For instance, this occurs if mothers are less likely to be employed (or work fewer hours) if their children have health or developmental problems.

\section{Data and Descriptive Results}

Data for this project are from the National Longitudinal Survey of Youth, a national sample of U.S. residents born between January 1, 1957 and December 31, 1964 who have been surveyed since 1979. ${ }^{15}$ In 1982 the NLSY began including questions on pregnancy, pre-natal, and post-natal care. Information on children born to and living with female NLSY respondents, referred to as the Children of the NLSY, has been collected at two year intervals beginning in 1986 with information used below through 1996. The combined data set provides a unique source of longitudinal information on a large sample of children and their parents, including great detail on maternal, child, and household characteristics, and various child assessments.

The NLSY (through 1996) supplies data on children born to women aged 29 to 38 at the end of 1995. This covers approximately 80 percent of childbearing for this cohort but is not completely representative of all fertility, since some children born to older mothers (who tend to have high incomes and education levels) are excluded. This selection should be kept in mind when interpreting the results. However, the sample is more representative than that in almost all previous studies. As shown in Table 1, prior research typically used only the 1986 or 1988 waves of the NLSY, when less than half of the cohort's fertility had occurred.

\footnotetext{
${ }^{15}$ The NLSY originally included a representative sample of 6,111 youths, an oversample of 5,295 blacks, Hispanics and economically disadvantaged whites, and a supplemental sample of 1,280 persons in the military in September 1978. Interviews with the military subsample were suspended after 1984 and for economically disadvantaged non-Hispanic whites after 1990. This data set is now sometimes referred to as the NLSY79, to distinguish it from the new NLSY97 survey which covers a younger cohort.
} 
Cognitive development is proxied by scores on the Peabody Picture Vocabulary Test (PPVT) and the Peabody Individual Achievement Test Reading Recognition subtest (PIAT-R) and Mathematics subtest (PIAT-M). ${ }^{16}$ These are among the most widely used assessments of preschool and early school-aged children and are known to have high test-retest reliability and concurrent validity (Baker et al., 1993). The PPVT measures receptive vocabulary for Standard American English and provides a quick estimate of verbal ability and scholastic aptitude. The PIAT-M measures attainment in mathematics beginning with early skills, such as recognizing numerals, and progressing to advanced concepts in geometry and trigonometry. The PIAT-R measures word recognition and pronunciation ability; skills examined include matching letters, naming names, and reading single words aloud.

The PPVT was administered to children aged 3 and over in 1986, with additional assessments for previously untested age-eligible children in 1988, 1990, 1992, 1994, and 1996 . $^{17}$ This investigation examines results for 3 and 4 year olds. The PIAT-M and PIAT-R were given to children 5 and over in each survey year; this project uses data on 5 and 6 year olds. ${ }^{18}$ The analysis below focuses on the "standard" cognitive assessment scores. These represent transformations (on an age-specific basis) of the raw scores that were originally (during the 1970s) designed to have a normal distribution with a mean of 100 and a standard deviation of 15. Standard scores have been commonly used by previous researchers (e.g. Baydar \& BrooksGunn, 1991; Blau \& Grossberg, 1992, Parcel \& Menaghan, 1994); however, some models are also estimated using raw and "percentile" scores, to insure that the results are not sensitive this choice. ${ }^{19}$ For ease of interpretation, the dependent variables have been normalized to have a

\footnotetext{
${ }^{16}$ The PPVT test in the NLSY is a revised version of the original assessment and is frequently abbreviated as the PPVT-R.

${ }^{17}$ All age-eligible children were assessed in 1992, even if they had previously been tested.

${ }^{18}$ Reading comprehension is also assessed for children receiving sufficiently high PIAT-R scores. However, this test rarely provides useful information for children under 7 and is not utilized here.

${ }^{19}$ The percentile scores are derived from the standard scores and represent the ranking of individuals in the age-normed distribution. Thus, they were uniformly distributed for the original norming population. The raw scores are closer to a log-normal distribution, particularly for the PIAT-R and PIAT-M assessments. One implication is that the percentile scores will tend to place more weight on observations in the middle of the distribution and raw scores on those at its upper-tail than will the standard scores.
} 
standard deviation of one. Therefore, the regression coefficients show the standard deviation change in the test score predicted by a one unit change in the explanatory variable.

Maternal employment is measured for the quarter prior to pregnancy (the fourth quarter before birth), the pregnancy period (the next 3 quarters), and the first through fourth years of the child's life. Although most regressions control for average weekly employment hours divided by 40 , the proportion of weeks worked is sometimes examined as an alternative. ${ }^{20}$ Thus, a one unit change in the labor supply variable corresponds to switching from no employment to 40 hours per week of work or from never holding a job to working in every week of the period.

Information is also available on when prior to delivery the mother stopped working and how soon after it she returned to a job. These data are used to analyze decisions to stop and restart employment during the period surrounding birth.

The NLSY contains limited information on the employment of fathers who reside with interviewed mothers. Specifically, data on hours or weeks worked in the calendar year preceding the survey date are used to construct variables indicating average weekly work hours (divided by 40) or the proportion of weeks worked during the year. ${ }^{21}$ The analysis of paternal employment is restricted to children with fathers living in the household at the interview date of the fourth calendar year after birth, since these men are likely to have been with the child during the first three years. For children born before (on or after) July 1, year 1 refers to the calendar year of birth (the next calendar year). Thus, year 1 includes the majority of the child's first year of life. Years 2 through 4 are defined in reference to year $1 .^{22}$

This analysis exploits the extensive child, maternal, and household information available in the NLSY. The vector of background variables, labeled "basic" characteristics because they

\footnotetext{
${ }^{20}$ Work weeks and hours cover all jobs held by the respondent. In the few cases where information on secondary jobs is missing, the variables are calculated using data for the main job only. NLSY mothers with a job but on maternity leave are generally categorized as employed. Thus, employment rates immediately after birth will be overstated and the effects of maternal work during this period may be underestimated. However, few women are on maternity leave for more than a few weeks (Klerman \& Leibowitz, 1994), so the resulting bias is likely to be small.

${ }^{21}$ The more detailed employment history included for mothers is not available for spouses.

${ }^{22}$ Father's weeks worked are not reliably reported prior to 1981 (there are virtually no observations with zero weeks.) Therefore, the data on paternal employment are restricted to the period after 1980.
} 
have frequently been controlled for in previous research, contains continuous measures of birth order, mother's age at child birth (in years), her highest grade completed, and a quadratic for child age (in months). Also included are dummy variables for race/ethnicity (2 variables), residence in an SMSA or central city (2 variables), and sex of the child. Unless otherwise noted, all explanatory variables are measured as of the child assessment date. Table A.1 provides a detailed description of the variables used in this analysis.

A second set of regressors, called "supplemental" characteristics encompass personal and household information that has generally not been held constant in prior work such as: the mother's number of siblings, her Armed Forces Qualifications Test (AFQT) score, place of birth, location at age 14 (3 variables), and whether magazines, newspapers, or library cards were in her home at 14 (3 variables). Also included are data on the relative ages of the child's siblings (4 variables), the mother's marital status at the survey date before pregnancy and the next 3 surveys (8 variables), the place of birth and education of her parents, her family structure at age 14, whether she attended a public or private secondary school, if the child's father lived in the home at the assessment date, and whether family income was below the poverty line in the second calendar year before the child's birth. ${ }^{23}$ These characteristics may directly influence the quality of home investments or proxy unobserved determinants of them.

"Attitude" characteristics control for maternal attitudes and experiences that may be correlated with factors affecting child outcomes. These include religious affiliation and church attendance in 1979 (6 variables), age at which the mother smoked her first cigarette (4 variables), drug use prior to age 21 (4 variables), and her cumulative score on a family roles attitude scale. ${ }^{24}$

"Pregnancy behaviors and birth outcomes" indicate pregnancy characteristics and early child health or developmental problems that might affect future cognitive attainment and be

\footnotetext{
${ }^{23}$ Poverty status in the second year prior to birth is used to avoid confounding caused by any changes in employment during pregnancy.

${ }^{24}$ The scale was constructed by assigning a value of 0 or 1 to each of eight questions and then summing the results. Higher scores indicate greater work orientation and less traditional attitudes. For instance, one was added to the scale for women who disagreed or strongly disagreed with the statement "a wife who carries out her full family responsibilities doesn't have time for outside employment" and for those who agreed or strongly agreed that "men should share the work around the house with women, such as doing dishes, cleaning, and so fourth".
} 
correlated with maternal employment. Included are indicators of low birth weight (4 variables), premature births (3 variables), long hospital stays at birth, hospitalization during the first year of life, physician visits related to illness in the first 12 months, excessive or deficient weight gain by the mother during pregnancy (3 variables), height-adjusted weight prior to pregnancy (4 variables), smoking and alcohol consumption during pregnancy ( 2 variables). ${ }^{25}$ This information is used cautiously below, since employment in year 1 could affect infant health.

"Maternal employment characteristics" control for weekly work hours in the fourth quarter prior to birth, during pregnancy, and in year 4, as well as hourly wages (6 variables) and the mother's occupation (6 variables) in the fourth quarter before birth. These variables supply information on the opportunity costs of not working in the early years and may be correlated with unobserved parental influences on child development. Some models hold constant family incomes and the use or type of day care. Finally, age and highest grade completed by the father (in the calendar year of birth) are controlled for when analyzing paternal employment.

Data on one or more background characteristics are missing for some respondents. To avoid excluding these persons, the relevant regressors were sometimes set to zero and dummy variables created denoting the presence of missing values. For example, mothers not reporting an AFQT score were given a value of zero and the "missing AFQT" variable was set to one. ${ }^{26}$ Alternatively, some dummy variables were given a one when the specified condition was met and a zero when either it was not or the relevant data were missing. ${ }^{27}$

\section{D.1 Patterns of Maternal Employment}

Figures 1 through 5 provide descriptive information on maternal employment during pregnancy and the first three years of the child's life. Data are from the nationally representative

\footnotetext{
${ }^{25}$ Height-adjusted weight is categorized by body mass index (BMI) - weight (in kilograms) divided by height (in meters) squared. Height is measured in 1981 and weight immediately before pregnancy.

${ }^{26}$ This strategy was used for number of siblings, marital status, age of smoking initiation, location and language spoken in the home at 14, presence of the father in the household, poverty status before birth, education of the mother's parents, birth weight, and gestational age. If information on maternal education was missing when the child was 3 or 4 but available for ages 5 and 6 , or vice versa, the earlier or later value was used.

${ }^{27}$ For example, this was done for hospitalizations or doctor visits in the first year, pregnancy behaviors, and residence in an SMSA at the survey date.
} 
subsample of the NLSY, although similar results are obtained using weighted data for the full sample. Figure 1 displays histograms of weeks worked during the specified period. There is always substantial bunching at the extremes of employment in all weeks or none at all - these two categories account for 55 percent of pregnant women, 54 percent of mothers during year 1, and 63 percent in years 2 and 3 . There is somewhat more dispersion in work hours, but Figure 2 demonstrates that most women either do not hold jobs or work quite intensively. For instance, 66 percent are not employed or average more than 30 hours per week during pregnancy, as do 64,66 , and 66 percent in the first, second, and third years of the child's life. ${ }^{28}$

The concentration of employment is more sharply highlighted in Figure 3, which calculates average hours in weeks of work. Conditional on some employment, between 26 and 35 percent of women work exactly 40 hours per week and 67 to 74 percent average 30 or more hours. By contrast, fewer than 1 in 4 (1 in 6) are employed less than 25 (20) hours per week. Thus, most mothers with young children either do not hold jobs or work close to full-time, suggesting that the econometric analysis is likely to obtain similar results whether controlling for average work hours or the proportion of weeks worked.

The "unconditional" probabilities in Figure 4 indicate that 72 percent of mothers hold jobs while pregnant but less than one-fourth ( 24 percent) do so until giving birth. The "conditional" estimates show employment probabilities for those working at some point during pregnancy and demonstrate that one-third of such women remain employed until delivery. The figure also illustrates that weekly hazard rates out of employment (displayed in percent terms and multiplied by 5) are less than 2 percent per week during the first two-trimesters of pregnancy, before increasing to around 3 percent in the seventh month, 4 to 5 percent in month 8 , and then rising to almost 20 percent in the week before birth.

Figure 5 summarizes reemployment rates following the birth. One-fourth of mothers are absent from jobs for less than one week after delivery, although some "employed" women may initially be on maternity leave. Weekly reemployment hazard rates average 4 to 8 percent for the next 10 weeks and then decline rapidly to 1 to 2 percent in the fourth through sixth months of the

\footnotetext{
${ }^{28}$ Work hours are top-coded at 50 in the histograms for expositional convenience.
} 
child's life and less than 1 percent for the remainder of the first year. The hazard rates typically range between 0.2 and 0.6 percent per week during the second year and 0.1 to 0.2 percent in year 3. Seventy-seven (84) percent of women return to jobs by their child's second (third) birthday, as do 70 (79) percent of those taking some time off work after birth.

\section{D.2 Paternal Employment}

Most mothers stay home with their infants for a substantial period of time. The same is not true of fathers. As detailed in the top half of Figure 6, 64 percent of men hold jobs in all 52 weeks of year 1 and 84 percent are employed at least 10 months; conversely, only 3 percent do not work at all during the period and just 8 percent for less than 6 months. ${ }^{29}$ Similarly, 41 percent of fathers are employed in all weeks of the first three years and 84 percent average 10 or more months of work annually. By contrast, less than 1 percent do not hold a job in any week and fewer than 4 percent work in less than half of them.

There are at least four reasons to believe that most joblessness does not occur because fathers are choosing to invest time in young children. First, the nonemployment is approximately evenly distributed across the first three years, rather than being concentrated in the year 1 as expected if the absences are motivated by a desire to be with infants. ${ }^{30}$ Second, over half (53 percent) of nonemployment is spent on temporary layoff or looking for new work, suggesting that most work absences are involuntary. ${ }^{31}$ Third, fathers with substantial joblessness possess characteristics associated with employment instability, implying that their time away from work may be due to these factors. ${ }^{32}$ Fourth, time-diary evidence analyzed by Hofferth (1999) indicates that nonworking fathers spend less time with their children than employed men.

\footnotetext{
${ }^{29}$ The information in this section refers to fathers living with mothers in the nationally representative subsample of the NLSY at the survey date of the fourth year after birth.

${ }^{30}$ Among fathers jobless for less than six months during the three years ( 84 percent of the sample), 34 percent of the weeks occur during year 1 and 31 percent in year 3. By contrast, 63 percent of weeks corresponding mothers are off work occur during the first year and just 22 percent in year 3 .

${ }^{31}$ A larger proportion of nonemployment is devoted to job search or spent on layoff in year 1 than in years 2 and 3, which would not be expected if fathers were choosing to spend time with infants.

${ }^{32}$ For instance, 28 percent of fathers jobless at least six months during the three years had less than 12 years of education, compared to 11 percent of those out of work fewer than 26 weeks; 28 percent of the former group were under the age of 25 versus 19 percent of the latter.
} 
The bottom half of Figure 6 shows the distribution of paternal hours in weeks of employment. ${ }^{33}$ Once again, there is considerable bunching around 40 hours per week - over half of men work exactly this amount in year 1 . However, in sharp contrast to mothers, a large proportion of fathers also work considerably longer hours. For example, 38, 29, and 12 percent average at least 45, 50, and 60 hours of work per week in year 1 and 41, 23, and 8 percent do so throughout the first three years. Conversely, only 10 percent of mothers average 45 or more hours in weeks of employment during the child's first year.

\section{D.3 Descriptive Relationships}

Children with employed mothers have relatively high levels of cognitive achievement. As shown on the top panel of Table 2, maternal employment of 30 or more hours per week is associated a .2 to .3 standard deviation increase in PPVT, PIAT-R, and PIAT-M scores, compared to nonworking women. Conversely, few differences are associated with part-time employment (compared to full-time work). The bottom panel of the table demonstrates the need for caution in placing any causal interpretation on these results, however, since the backgrounds of children with nonworking mothers differ markedly in other ways as well. For example, nonemployed women have relatively limited education, low AFQT scores, are much more likely have been poor prior to pregnancy, and have high rates of low birth weight. These and other factors are likely to be important sources of at least some of the disparities in child outcomes, suggesting the need for a careful multivariate investigation.

\section{E. Regression Estimates}

The econometric analysis first examines the relationship between maternal employment and the PPVT scores of 3 and 4 year olds. This outcome has received the most attention in prior studies and the results obtained can be directly compared to that work. The reading and mathematics skills of 5 and 6 year olds are considered next, followed by tests of the sensitivity of the estimates to changes in samples or regression models.

Table 3 displays the findings of 10 specifications for each of the three cognitive assessments. The dependent variables in models (a) through (h) are standard test scores,

\footnotetext{
${ }^{33}$ Hours are top-coded at 70 in the histograms for expositional convenience.
} 
normalized to have a standard deviation of one. The last two columns show results for the (similarly normalized) percentile and raw scores. Maternal employment refers to average weekly work hours (divided by 40) in the specified period, except for column (h) which controls for the fraction of weeks worked. Year 1 includes the first through fourth quarters after birth and years 2 and 3 to the fifth through twelfth quarters subsequent to it. All models include assessment year dummy variables. Additional regressors are detailed at the bottom of the table: $\mathrm{B}, \mathrm{F}, \mathrm{A}, \mathrm{C}$, and $\mathrm{E}$ refer to the vectors of basic, supplemental, and maternal employment characteristics described previously and detailed in Table A.1; I indicates controls for total family income (\$1996) during the calendar year before birth and the next 4 years. ${ }^{34}$

\section{E. 1 Verbal Skills of 3 and 4 Year Olds}

The top panel of Table 3 summarizes the results for PPVT scores. Column (a) controls only for maternal employment and the assessment year. As in the descriptive analysis, 3 and 4 year olds with working mothers have relatively high verbal ability - switching from no job to 40 hours of employment per week during the first (second and third) year of life is associated with a .10 (.21) standard deviation rise in the PPVT score. However, much of this is due to confounding factors rather than maternal job-holding. Thus, inclusion of the basic set of covariates substantially reduces the parameter estimate for years 2 and 3 and switches the year 1 coefficient from positive to negative (model b). Taken at face value, these results suggest harmful "effects" of maternal employment during the first year but with roughly offsetting benefits for working during the next two years and closely resemble the findings of previous researchers using similar models. However, the estimates are not robust to further controls for heterogeneity. For instance, the supplemental characteristics added in column (c) virtually eliminate the predicted benefit of working in years 2 and 3. Once this is done, however, the extra variables in specifications (d) and (e) have little additional effect.

\footnotetext{
${ }^{34}$ This includes income from jobs, business/farm activities, government transfers (AFDC, Food Stamps, $\mathrm{SSI} /$ public assistance, unemployment insurance, veteran's/disability benefits), alimony, and child support.
} 
Since labor supply is correlated over time, models (a) through (e) could combine the effects of working in the first three years of life with those of jobs held at earlier or later dates. ${ }^{35}$ Previous and subsequent employment might also proxy some of the remaining heterogeneity. For these reasons, column (f) adds controls for maternal employment characteristics during pregnancy, in the quarter before it, and in year 4. Their inclusion strengthens the negative predicted effect of working during year 1 (to .13 standard deviations), while modestly increasing the (insignificant) positive coefficient for years 2 and 3. In this specification, a 40 hour per week increase in employment throughout the first three years is correlated with a .07 standard deviation decline in PPVT scores. These results suggest that maternal employment has more negative effects than have been indicated by prior studies using less comprehensive controls for maternal, family, and child characteristics.

Maternal job-holding could benefit children by raising earnings. If so, the employment coefficients would decline when income is held constant. However, as shown in specification (g), controlling for family income has little effect on parameter estimates. A possible explanation is that work is associated with decreases in other sources of financial support (e.g. transfer payments or spousal earnings), so that family incomes actually do not rise very much. However, the direct income effects, estimated from the regressions, are also small.

Column (h) differs from model (f) by controlling for the proportion of weeks worked, rather than average weekly work hours. In models (i) and (j), percentile and raw scores, rather than the standard scores, are the dependent variables. Holding constant weeks rather than hours of work attenuates the estimated effects, as expected since some variation in hours occurs within weeks of employment, but only slightly. The negative impact predicted for job-holding in year 1 is somewhat greater when using percentile scores and that for employment in years 2 and 3 slightly smaller for the raw scores, however neither difference is large or significant. Thus, the predicted impact of maternal employment appears to be robust to these changes in specification.

\footnotetext{
${ }^{35}$ The correlation between hours of work during pregnancy and year 1 is .700 , for the representative NLSY subsample. The correlation between years $2 / 3$ and year 4 is .754 .
} 


\section{E.2 Are the Results Consistent Across Alternative Cognitive Assessments?}

The findings above suggest that previous research focusing on the PPVT scores of 3 and 4 year olds may have presented an overly optimistic evaluation of the effects of early maternal employment. This section demonstrates that the relationship between job-holding and child development is also sensitive to the age of testing and the skills assessed, with more negative results obtained when considering 5 and 6 year old children.

PIAT-R and PIAT-M assessments are the dependent variables in the middle and bottom panels of Table 3. The patterns of changes in parameter estimates across specifications are broadly consistent with those for PPVT scores. Absent covariates other than the survey year, there is again a positive association between maternal employment and cognitive achievement (column a). The correlation shrinks and loses statistical significance when the "basic" regressors are included (column b), declines further or becomes negative when supplemental characteristics are added (specification c), but with little additional change for the extra controls in models (d) and (e). The coefficients decrease still more when maternal employment characteristics are held constant (column f). Finally, the inclusion of family incomes (specification g) does not materially affect the results, and similar parameter estimates are obtained when the fraction of weeks worked are controlled for or when percentile or raw scores are the dependent variables (models h through j).

Despite these similarities, the expected impact of early employment is markedly more negative for 5 and 6 year olds than it was for younger children. Most strikingly, job-holding during years 2 and 3 is predicted to have strongly detrimental impacts on PIAT-R and PIAT-M performance. In specification (f), 40 hours per week of additional work is associated with statistically significant .15 and .12 standard deviation reductions in reading and mathematics scores. This contrasts with a small positive correlation for the PPVT assessment. As a result, switching from no work to full-time employment throughout the first three years is predicted to lower PIAT-R and PIAT-M scores by .24 and .16 standard deviations, compared to a much smaller .07 standard deviation decrease in expected PPVT performance. 


\section{E.3 Timing and Interaction Effects of Early Maternal Employment}

Specifications with separate controls for work hours in years 2 and 3, summarized in the top panel of Table 4, indicate that parental time investments during the second year of the child's life are particularly important for the reading skills of 5 and 6 year olds, whereas those occurring in year 3 are more crucial for mathematics. ${ }^{36}$ Thus, a 40 hour increase in weekly labor supply during year 2 reduces predicted PIAT-R scores by a statistically significant .13 standard deviations, with no change in expected PIAT-M performance. A corresponding rise in work hours during the third year is unrelated to reading achievement but is predicted to reduce math scores by a statistically significant .12 standard deviations. Combined with the results for PPVT scores, these findings suggest that the returns to parental time investments vary with the age of the child and the type of cognitive skills considered.

Maternal employment during years 2 and 3 raises the expected verbal scores of 3 and 4 year olds by about half as much as job-holding in the first year is predicted to reduce them. This could occur because infants suffer losses when their mothers work but "catch-up" if the employment continues for the next 2 years. Alternatively, the latter gains may be concentrated among children whose mothers were not employed in year 1. The reductions in the PIAT-R and PIAT-M scores associated with work in the second and third year could similarly vary with labor force status in the first year.

To address these issues, the bottom panel of Table 4 allows the employment coefficient for years 2 and 3 to differ depending on whether or not the mother worked in year 1 . The results indicate that labor supply in the later period has more favorable effects if no job was held during in the first year. For example, switching from 0 to 40 hours of work per week in years 2 and 3 raises predicted PPVT scores by .10 standard deviations if the mother was not employed in year 1 but by half as much if she was. The same change lowers the expected reading scores of 5 and 6 year olds by .11 standard deviations conditional on no job in year 1, with no effect on predicted math performance, but is anticipated to reduce PIAT-R and PIAT-M scores by .17 and .16

\footnotetext{
${ }^{36}$ Except where noted otherwise, the remaining estimates control for the same covariates as column (f) of Table 3 and use standard test scores as outcomes.
} 
standard deviations if the mother also worked in the first year. This supplies further evidence of the importance of time investments during infancy.

\section{E.4 Employment Exit and Reentry}

An important decision made by mothers is when (if at all) during pregnancy to stop work and how soon after birth to resume employment. To address these issues, I estimated models with controls for average weekly work hours replaced by quadratics in the number of weeks before birth the mother left employment (BEFORE) and after it (AFTER) until she returned to a job. ${ }^{37}$ These regressions (not shown) suggest that PPVT, PIAT-R and PIAT-R scores reach a maximum when mothers stay away from jobs for 90, 113, and 153 weeks after delivery. Compared to an immediate resumption of employment, absences of this length increase expected test performance by $.09, .19$, and .11 standard deviations. ${ }^{38}$ Thus, by this criteria, the "optimal" post-birth employment absence exceeds 20 months for the verbal ability of 3 and 4 year olds and two years for the reading or mathematics achievement of 5 and 6 year olds. These findings are broadly consistent with the previously obtained results controlling for average work hours.

\section{E.5 Subsamples}

Table 5 summarizes the findings of models estimated for population subgroups. The specifications are the same as column (f) of Table 3, except that a combined indicator of employment during the first three years is used. Full sample results, displayed in the top panel, confirm that maternal job-holding has a small statistically insignificant negative predicted effect on PPVT scores and a larger deleterious impact on expected PIAT-R and PIAT-M performance. Switching from no work to full-time employment is predicted to reduce the three cognitive scores by $.04, .23$, and .16 standard deviations respectively.

\footnotetext{
${ }^{37}$ BEFORE was top-coded at 40 , since weeks greater than 40 imply no employment during pregnancy. AFTER was top-coded at 156, reflecting the focus of this paper on employment during the first three years. I also augmented the models with dummy variables indicating no work during pregnancy and a return to a job within one week of giving birth, under the assumption that this might capture some otherwise uncontrolled for heterogeneity. However, the inclusion of these variables never materially affected the results.

${ }^{38}$ The p-values on the null hypothesis of no effect are $.251, .002$, and .113 .
} 
The second panel limits the analysis to first-born children. The impact of maternal employment on younger siblings could be influenced by family dynamics not fully accounted for in the econometric models. For example, the health or psychological problems of an older child might affect both maternal job-holding and the allocation of non-market time between children. However, the estimates are similar to those for the full sample - a 40 hour increase in weekly employment reduces PPVT, PIAT-R, and PIAT-M performance by .10, .23, and .12 standard deviations - suggesting that these omissions do not introduce serious bias.

Time and income are likely to be particularly limited in single-parent households, and family composition could be correlated with characteristics affecting the quality of time investments or of the home environment. These possibilities are investigated in the third and fourth panels of Table 5. The "father present" category refers to children whose biological fathers are in the household on the survey date of the fourth calendar year after birth. The "father not present" results are for children whose fathers are not in the home at that time. The "spouse present" and "spouse not present" subsamples are divided by whether a husband (not necessarily the biological father) is in the household during all or none of the survey dates in the first three calendar years following the child's birth. ${ }^{39}$

Given the relatively small sample sizes, the employment coefficients are estimated imprecisely. Nevertheless, the results hint that maternal job-holding is more harmful for "traditional" than "nontraditional" families. Thus, early employment is negatively related to PPVT scores for two-parent families but positively correlated with them in female-headed households. A similar pattern holds for the reading and math skills of 5 and 6 year olds, although there is some variation across outcomes and stratification criteria. These findings are consistent with the possibility that the quality of the home environment or of parental time is relatively high in two-adult families, or that the income provided by maternal employment is especially beneficial in those headed by the mother.

\footnotetext{
${ }^{39}$ Children with a male adult present in some but not all years are excluded from this analysis.
} 
The last panel divides the sample into working women earning more or less than $\$ 10$ per hour (\$1996) in the fourth quarter before birth. ${ }^{40}$ Maternal employment is negatively related to the PPVT scores of high but not low earners, which is consistent with the possibility that the mother's earnings yield relatively large benefits when wages are low. However, a similar result is not obtained for the PIAT-R or PIAT-M assessments.

\section{E.6 Alternative Specifications}

The robustness of the results was tested across a variety of alternative econometric specifications. Potential nonlinearities in the effects employment were examined by including a quadratic for maternal work hours or dummy variables indicating hours above or below specified thresholds (e.g. 25 hours per week). These estimates generally indicated a monotonic relationship between labor supply and cognitive outcomes, although with some suggestion that employment exceeding 20 hours per week in the first (second and third) year had particularly negative effects on PPVT (PIAT-R and PIAT-M) performance.

The impact of maternal job-holding was allowed to differ across high and low achievers through a series of quantile regression models examining the $10^{\text {th }}, 25^{\text {th }}, 50^{\text {th }}, 75^{\text {th }}$, and $90^{\text {th }}$ percentiles of the test scores. These estimates did not reveal a pattern of differential effects across achievement levels for the PIAT-R and PIAT-M assessments. Conversely, employment was predicted to have more negative impacts on high than low PPVT scores; the coefficient (standard error) on average weekly hours in years 1 through 3 was .113 (.089), .005 (.095), -.066 $(.062),-.105(.075)$, and $-.196(.079)$ at the $10^{\text {th }}, 25^{\text {th }}, 50^{\text {th }}, 75^{\text {th }}$, and $90^{\text {th }}$ percentiles. $^{41}$

Fixed-effect models were estimated by restricting the sample to siblings and including a vector of mother-specific dummy variables. As discussed, these models will understate the costs of maternal employment if women supply less labor when their children have health or developmental problems. The results are consistent with this expectation. The FE estimate (standard error) for average weekly work hours in years 1 through 3 is .077 (.095), -.166 (.101) and -.114 (.104) for PPVT, PIAT-R and PIAT-M scores, compared to corresponding OLS results

\footnotetext{
${ }^{40}$ Women not working at this time are excluded. Other wage thresholds were also considered.

${ }^{41}$ The standard errors are bootstrapped estimates obtained by resampling the data 20 times.
} 
of $-.058(.095),-.282(.069)$, and $-.188(.070) .{ }^{42}$ However, even with a likely upwards bias, the point estimates from the FE models suggest a negative relationship between early maternal employment and the reading or mathematics achievement of 5 and 6 year olds.

A final set of specifications added controls for the incidence or duration of breastfeeding, which has been linked to improved cognitive development (Anderson, Johnstone, and Remley, 1999). Working mothers are less likely to breast-feed, which could explain a portion of the negative effect of maternal employment, particularly during the first year. However, the results provide little support for this possibility. Breast-feeding is positively associated with the assessment scores but its inclusion only slightly reduces the magnitude of the year 1 employment coefficient, and has no impact for working in years 2 and $3 .^{43}$

\section{F. Child Care}

Nonparental child care has been ignored until now. One concern is that the type or amount of care might be influenced by work decisions, in which case controlling for it might inappropriately attenuate the effects of maternal employment. However, the impact of jobholding could also vary with day care arrangements. For instance, the negative effects of working might be due to the low average quality of nonparental care in the United States. ${ }^{44}$ This section addresses these issues by incorporating a limited analysis of child care. The NLSY is less than ideal for this purpose. Information is available on the number and type of arrangements but not (after 1989) on the intensity, cost, or quality of care. Also, the family background characteristics controlled for are likely to better account for heterogeneity in the home environment or parental time investments than of child care, implying a greater role for omitted variables bias. These restrictions should be kept in mind when interpreting the results.

The first panel of Table 6 displays the percentage of children, in the nationally representative subsample of the NLSY, receiving nonparental care during the first three years

\footnotetext{
${ }^{42}$ The sample sizes were 3111,3596 , and 3686 for the PPVT, PIAT-R and PIAT-M scores.

${ }^{43}$ The most significant change is that the coefficient for year 1 work hours on PIAT-M scores increases from -.036 without controls for breast-feeding to -.033 (-.021) when the incidence (duration) of breastfeeding is held constant.

${ }^{44}$ Helburn \& Howes (1996) indicate that 86 percent of day care centers provide "mediocre or poor" services and that only 9 percent of family child care homes supply "good" quality care.
} 
and the type of the first arrangement of that care. ${ }^{45}$ The second panel shows the fraction receiving any day care or center-based care, as a function of maternal work hours. Employment and child care are closely connected - over 85 percent of mothers working 30 or more hours per week use nonparental care, compared to less than one-fifth of women who do not hold jobs. Day care use also rises with child age, from 44 percent in year 1 to 54 percent in year 3, because nonemployed mothers are more likely to place toddlers (than infants) in care and since women with older children are more likely to work. Interestingly, the increase in day care use between the first and third year is entirely accounted for by growth in center-based care. Also, relatively few children are placed in multiple types of care during a single year, implying that little information is lost by focusing on the first arrangement.

Table 7 summarizes the results of econometric models that include interactions between maternal work hours and the use of day care or the type of the first arrangement. ${ }^{46}$ The first row of column (a) shows the predicted effect of full-time employment but no nonparental care. The second row indicates the additional impact of placing the child in day care; specification (b) illustrates the corresponding differentials associated with alternative types of care.

Holding maternal work hours constant, nonparental care does not have a consistent relationship with child cognitive development. Children placed in care during the first year have slightly lower verbal ability at ages 3 and 4 but marginally higher levels of reading or mathematics achievement two years later (see model a), although fairly large standard errors imply that these results need to be interpreted with caution. Day care in years 2 and 3 is associated with insignificantly higher PPVT and PIAT-M scores but with no difference in PIAT$\mathrm{R}$ performance. Interestingly, the estimates in specification (b) hint that children in center-based care during the first year of life do relatively poorly, whereas the reverse is true when this

\footnotetext{
${ }^{45}$ Types of care are not mutually exclusive. For example, a child can be cared for by a relative in the mother's home.

${ }^{46}$ The regression model is: $C_{i t}=\alpha+X_{i t} \beta+H_{i t-j} \gamma+H_{i t-j} D_{i t-j} \delta+\varepsilon_{i t}$, where $D_{i t-j}$ indicates whether nonparental care is used or the type of the first arrangement. Table 7 displays $\hat{\gamma}$ and $\hat{\delta}$. The child care arrangements are defined here so as to be mutually exclusive. When the first arrangement in year 2 is with a relative but in year 3 it is in a center, the combined year 2 and 3 dummy variable for relative care is set to 1 , while that for center-based care is coded as 0 .
} 
arrangement is chosen in years 2 and 3. Generally, these results conform to prior research finding small and inconsistent effects of nonparental care on child development. Most importantly for this analysis, the addition of controls for day care has little impact on the results for maternal employment.

\section{G. What About Fathers?}

The preceding analysis suggests the importance of maternal time investments. But what about fathers? While it is possible that mothers provide unique inputs, it seems likely that there is at least some substitutability of time investments between parents. Since men are typically paid more than women, however, larger income benefits could accrue to paternal employment.

These issues are addressed in Table 8, which summarizes econometric results for NLSY children with both parents in the household on the interview date of the fourth calendar year after birth. Parental employment refers to average weekly work hours (divided by 40) during years 1 through 3. Column (a) holds constant maternal hours, as well as the standard set of covariates. The labor supply of mothers is once again estimated to have a small and insignificant negative impact on the verbal ability of 3 and 4 year olds but substantial detrimental effects on the reading and math achievement of children aged 5 and 6 . Column (b) adds controls for paternal employment. This has virtually no effect on the estimates for maternal job-holding, indicating that the findings of previous sections are unlikely to be seriously biased by this omission, but suggests that the employment of fathers has a beneficial impact on children - working 40 extra hours per week throughout the first three years is associated with $.18, .07$, and .09 standard deviation increases in PPVT, PIAT-R, and PIAT-M scores.

This positive "effect" of paternal employment is probably due to omitted variables bias. As discussed, joblessness is concentrated among a relatively small fraction of fathers who are likely to provide low quality time investments. Regressions corresponding to specification (b), but controlling weeks rather than hours worked, reveal a strong positive relationship between weeks of employment and child test scores; switching from no work to employment in all 156 weeks is predicted to raise PPVT, PIAT-R, and PIAT-M performance by .40, .34, and .24 standard deviations (with standard errors of .10,.11, and .11). Such large positive correlations 
are to be expected if men working few weeks have unobserved characteristics associated with poor child outcomes. Column (c) partially addresses this possibility by including controls for the father's work hours in year 4 and his age and education in the calendar year of the child's birth. Doing so reduces the paternal employment coefficient for PIAT-R scores by over one-half but has little effect on the PPVT or PIAT-M parameter estimates. ${ }^{47}$

The remainder of the table details several strategies for better accounting for the heterogeneity between working and nonworking fathers. Specification (d) averages paternal hours over weeks of employment, rather than all weeks. ${ }^{48}$ These "conditional" averages are useful if differences in weekly employment probabilities are unrelated to desired time investments in children. The last 4 columns of Table 8 delete from the sample children whose fathers work less than a minimum number of weeks during years 1 through 3. Models (e) and (f) require employment in at least three-quarters of all weeks; columns $(\mathrm{g})$ and $(\mathrm{h})$ impose the more stringent criteria that joblessness totals 13 weeks or less. Given the high rates of paternal employment, relatively few children are excluded by these work restrictions - 12-13 percent in the first case and 24-25 percent in the second. At a minimum, these specifications show the effects of paternal hours for the vast majority of children whose fathers hold jobs most of the time. More optimistically, they may control for the heterogeneity associated with differences in weeks worked.

These estimates never reveal a large or significant positive correlation between paternal labor supply and the child outcomes. Instead, negative effects are quite commonly predicted. In column (d), a 40 hour per week increase in fathers' employment is associated with a .17 standard deviation reduction in PIAT-R scores and modest .05 and .04 standard deviation increases in PPVT and PIAT-M performance. The small gains for 5 and 6 year olds are eliminated when restricting the sample to children whose fathers have worked most of the first three years. For instance, in specifications (g) and (h), an extra 40 hours of weekly employment reduces

\footnotetext{
${ }^{47}$ I experimented with including paternal work hours in year 0 . The results were similar to those shown but are more difficult to interpret because of the larger number of missing values.

${ }^{48}$ Children whose fathers do not work at all during the three years (less than one percent of the sample) are excluded.
} 
anticipated PIAT-R (PIAT-R) performance by .16 to .17 (.07 to .09) standard deviations. These decreases are one-half to three-quarters as large as those predicted for corresponding maternal job-holding. ${ }^{49}$

The coefficients on maternal and paternal employment have the same signs in columns (e) through (h). This suggests that time investments of mothers and fathers have qualitatively similar effects on children, raising the possibility of substitution across parents. The stronger negative impacts observed for mothers could reflect actual differences. For instance, only women can breast-feed and men receive higher average wages, implying potentially larger income effects. Alternatively, they may occur because heterogeneity across fathers has been less adequately controlled for.

\section{H. Discussion}

This research suggests that parental investments at the beginning of life play an important role in fostering the cognitive development of children. Maternal employment in the child's first year is associated with lower verbal ability at ages 3 and 4, with only partially offsetting increases for working during the second and third year. When the reading and mathematics performance of 5 and 6 year olds are considered, the predicted effect of job-holding remains negative during the second and third years, and the cumulative effect of early employment appears quite detrimental. These findings suggest that prior research may have presented an overly optimistic assessment of the impact of work by mothers. Paternal employment is harder to examine because the data are less adequate and most periods of joblessness are likely to be unrelated to investments in young children. However, the analysis hints that fathers' time is also important, raising the possibility of substitution between maternal and paternal investments.

Our confidence in these results will be strengthened if future research confirms these patterns and identifies mechanisms for the effects. We need to better understand the role of child care, the impact of maternal labor supply on other child outcomes (e.g. health or socioemotional

\footnotetext{
${ }^{49}$ Specifications that include a quadratic in paternal work hours suggest that the negative effects for 5 and 6 year olds are concentrated among fathers employed relatively long hours. For instance, in models corresponding to specification (g), PIAT-R and PIAT-M scores are predicted to peak at 34 and 50 hours of work per week. However, the coefficients are imprecisely estimated.
} 
development), and the role of paternal employment. Notwithstanding these caveats, the estimates suggest that substantial cognitive gains accrue to children whose mothers stay home for at least two to three years after giving birth. For instance, working 40 hours per week throughout the first three years is associated with a .23 (.16) standard deviation reduction in the reading (math) performance of 5 and 6 year olds. Losses of this size are qualitatively significant - they are equivalent to those predicted by a 2 to 5 year increase in maternal education - and Currie \& Thomas (1999) provide evidence that early test scores have important effects on future educational and labor market outcomes, indicating that the cognitive gains may translate into lasting economic effects. ${ }^{50}$

By contrast, 77 (84) percent of the mothers in the representative portion of the NLSY return to work before their child's second (third) birthday. One possible reason is that there has been a concerted effort, since the mid-1980s, to increase the employment rates of women with young children through changes in welfare and Medicaid policies, the Earned Income Tax Credit, and government funding for child care (Meyer \& Rosenbaum, 1999). A second is that, even after enactment of the Family and Medical Leave Act, rights to maternity leave are limited in the United States compared with other industrialized countries. Evidence of deleterious impacts of maternal employment during the early years may be relevant for these policies.

Parental investments during infancy appear particularly important. Not only is maternal employment during this period associated with decreased verbal ability among 3 and 4 year olds, but work during the second and third years is correlated with especially low performance on all three cognitive assessments if the mother also held a job in the child's first year. This suggests potential benefits to children from expanded entitlements to parental leave or other "familyfriendly" policies that facilitate time at home with infants.

Child cognitive development is just one argument in the household utility function, however, raising the possibility of tradeoffs between this and other desirable outcomes. In addition, the consequences of parental employment are likely to depend on the technologies and

\footnotetext{
${ }^{50}$ Currie \& Thomas analyze the effects of reading test scores at age 7 on outcomes at age 33, using data from the British National Child Development Survey.
} 
institutional arrangements in place. For example, many European countries heavily subsidize child care as the first step in the system of public education. The effects of early job-holding could be quite different in such an environment. A better understanding of how the cognitive development of children is affected by parental employment might facilitate designing less costly ways of achieving the same benefits. These represent important topics for future research. 


\section{References}

Anderson, James W., Bryan M. Johnstone, and Daniel T. Remley. 1999. "Breast-feeding and Cognitive Development: A Meta-Analysis" American Journal of Clinical Nutrition, 70, 525535.

Baker, Paula C., Canada K. Keck, Frank L. Mott, and Stephen V. Quinlan. 1993. NLSY Child Handbook, 1986-1990. Columbus, OH: Center for Human Resource Research.

Baydar, Nazli and Jeanne Brooks-Gunn. 1991. "Effects of Maternal Employment and Child-Care Arrangements on Preschoolers' Cognitive and Behavioral Outcomes: Evidence from the Children of the National Longitudinal Survey of Youth" Developmental Psychology 27(6), 932-945.

Becker, Gary S. 1981. A Treatise on the Family. Cambridge, MA: Harvard University Press.

Belsky, Jay. 1988. "The 'Effects' of Infant Day Care Reconsidered” Early Childhood Research Quarterly, 3, 235-272.

Belsky, Jay. And Michael J. Rovine. 1988. "Nonmaternal Care in the First Year of Life and the Security of Infant-Parent Attachment" Child Development 59, 157-167.

Blau, David M., David K. Guilkey, and Barry M. Popkin. 1996. "Infant Health and the Labor Supply of Mothers” Journal of Human Resources 31(1), 90-139.

Blau, Francine D., Marianne A. Ferber, and Anne E. Winkler. 1998. The Economics of Women, Men, and Work, third edition. Saddle River, NJ: Prentice Hall.

Blau, Francine B. and Adam J. Grossberg. 1992. “Maternal Labor Supply and Children's Cognitive Development" The Review of Economics and Statistics 74(3), 474-481.

Carnegie Task Force on Meeting the Needs of Young Children. 1994. Starting Points: Meeting the Needs of Our Youngest Children. New York: Carnegie Corporation of New York.

Caughy, Margaret O’Brien, Janet A. DiPietro, and Donna M. Strobino. 1994. "Day-Care Participation as A Protective Factor in the Cognitive Development of Low-Income Children" Child Development 65, 457-471.

Clarke-Stewart, K. Alison. 1989. “Infant Day Care: Maligned or Malignant?” American Psychologist 44(2), February, 266-273.

Clarke-Stewart, K. Alison. 1991. "A Home is Not A School: The Effects of Child Care on Children's Development” Journal of Social Issues 47(2), 105-23.

Coleman, James S. 1988. "Social Capital and the Creation of Human Capital" American Journal of Sociology, 94, s95-s120. 
Council of Economic Advisers. 1999. Families and the Labor Market, 1969-1999: Analyzing the "Time Crunch". Washington, DC: Council of Economic Advisers, Executive Office of the President, May.

Council of Economic Advisers. 1997. The First Three Years: Investments that Pay. Washington, DC: Council of Economic Advisers, Executive Office of the President, April 17.

Currie, Janet and Duncan Thomas. 1999. "Early Test Scores, Socioeconomic Status, and Future Outcomes”, National Bureau of Economic Research Working Paper \#6943, February.

Currie, Janet and Duncan Thomas. 1995. "Does Head Start Make A Difference" American Economic Review 85(3), June, 341-364.

Desai, Sonalde, P. Lindsay Chase-Lansdale, and Robert T. Michael. 1989. "Mother or Market? Effects of Maternal Employment on the Intellectual Ability of 4-Year Old Children" Demography 26(4), November, 545-561.

Duncan, Greg J. and Jeanne Brooks-Gunn. 1997. "Income Effects Across the Life Span: Integration and Interpretation" in Greg J. Duncan and Jeanne Brooks-Gunn (eds.) Consequences of Growing Up Poor. New York: Russell Sage Foundation, 596-610.

Field, Tiffany M. 1991. "Quality Day-Care and Grade School Behavior and Performance" Child Development 62(4), August, 863-870.

Greenstein, Theodore N. 1995. "Are the "Most Disadvantaged" Children Truly Disadvantaged by Early Maternal Employment?” Journal of Family Issues 16(2), March, 149-169.

Grossman, Michael. 1972. "On the Concept of Health Capital and the Demand for Health" Journal of Political Economy 98(5, Part 1), 983-1007.

Harvey, Elizabeth. 1999. "Short-Term and Long-Term Effects of Early Parental Employment on Children of the National Longitudinal Survey of Youth" Developmental Psychology 35(2), 445-459.

Haveman, Robert and Barbara Wolfe. 1995. "The Determinants of Children's Attainments: A Review of Methods and Findings" Journal of Economic Literature 33(4), December, 18291878 .

Heckman, James J. 1999. "Policies to Foster Human Capital" National Bureau of Economic Research Working Paper No. 7288, August.

Helburn, Suzanne W. and Carollee Howes. 1996. "Child Care Cost and Quality" The Future of Children 6(2), Summer/Fall, 62-82.

Hofferth, Sandra L. 1999. "Women's Employment and Care of Children in the United States", mimeo, University of Michigan, August. 
Hoffman, L.W. 1980. "The Effects of Maternal Employment on the Academic Studies and Performance of School-Age Children” School Psychology Review, 9, 319-335.

James-Burdumy, Suzanne. 1998. "The Effect of Maternal Labor Force Participation on Child Educational Attainment”, mimeo, Johns Hopkins University, October.

Jessup, Amber. 1998. "Production of Child Health and Maternal Labor Supply", mimeo, University of North Carolina at Chapel Hill, November.

Juster, F. Thomas and Frank P. Stafford. 1991. "The Allocation of Time: Empirical Findings, Behavioral Models, and Problems of Measurement" Journal of Economic Literature 29(2), June, 471-522.

Karoly, Lynn A., Peter W. Greenwood, Susan S. Everingham, Jill Houbé, M. Rebecca Kilburn, C. Peter Rydell, Matthew Sanders, James Chiesa. 1998. Investing in Our Children: What We Know and Don't Know About the Benefits of Early Childhood Interventions. Santa Monica, CA: RAND.

Klerman, Jacob A. and Arleen Leibowitz. 1998. "FMLA and the Labor Supply of New Mothers: Evidence from the June CPS", mimeo, RAND, March.

Klerman, Jacob A. and Arleen Leibowitz. 1997. "Labor Supply Effects of State Maternity Leave Legislation" in Francine Blau and Ronald Erhenberg, eds., Gender and Family Issues in the Workplace. New York: Russell Sage Foundation, 65-85.

Klerman, Jacob A., and Arleen Leibowitz. 1994."The Work-Employment Distinction Among New Mothers" Journal of Human Resources, 29(2), 277-303.

Lamb, Michael E. and Sternberg, Kathleen J. 1990. "Do We Really Know How Day-Care Affects Children?" Journal of Applied Developmental Psychology, 11, 351-37.

Lazear, Edward and Robert Michael. 1988. Allocation of Income Within the Household. Chicago, IL: University of Chicago Press.

Leibowitz, Arleen. 1974. "Education and Home Production" American Economic Review, 64(2), May, 243-250. (1974a)

Leibowitz, Arleen. 1974. "Home Investments in Children" Journal of Political Economy, 82(2, part 2), s111-s131. (1974b)

Leibowitz, Arleen. 1977. "Parental Inputs and Children's Achievement" Journal of Human Resources, 12(2), 242-251.

Lindberg, Laura D. 1996. "Women's Decisions About Breastfeeding and Maternal Employment" Journal of Marriage and the Family 58(1), February, 239-251. 
Mayer, Susan E. 1997. “Indicators of Children's Economic Well-Being and Parental Employment" in Robert M. Hauser, Brett V. Brown, and William R. Prosser (eds.) Indicators of Children's Well-Being. New York: Russell Sage Foundation, 237-257.

McLanahan, Sara S. 1997. "Parental Absence or Poverty: Which Matters More? In Greg J. Duncan and Jeanne Brooks-Gunn (eds.) Consequences of Growing Up Poor. New York: Russell Sage Foundation, 35-48.

Meyer, Bruce D. and Dan T. Rosenbaum. 1999. "Welfare, the Earned Income Tax Credit, and the Labor Supply of Single Mothers", National Bureau of Economic Research Working Paper No. 7363.

Moore, Kristin A. and Anne K. Driscoll. 1997. "Low-Wage Maternal Employment and Outcomes for Children: A Study" The Future of Children 7(1), Spring 1997, 122-127.

Mott, Frank L. 1991. "Developmental Effects of Infant Care: The Mediating Role of Gender and Health” Journal of Social Issues 47(2), 139-58.

NICHD Early Child Care Research Network. 1997. "Familial Factors Associated With the Characteristics of Nonmaternal Care for Infants" Journal of Marriage and Family 59, May, 389-408. (1997a)

NICHD Early Child Care Research Network. 1997. "The Effects of Infant Child Care on InfantMother Attachment Security: Results of the NICHD Study of Early Child Care" Child Development 68(5), October, 860-879. (1997b)

Norberg, Karen. 1998. "The Effects of Daycare Reconsidered” National Bureau of Economic Research Working Paper \#6769, October.

Parcel, Toby L. and Elizabeth G. Menaghan. 1994. "Early Parental Work, Family Social Capital, and Early Childhood Outcomes” American Journal of Sociology 99(4), January, 972-1009.

Shore, Rima. 1997. Rethinking the Brain: New Insights Into Early Development. New York: Families and Work Institute.

Stafford, Frank P. 1987. “Women's Work, Sibling Competition, and Children's School Performance” American Economic Review, 77(5), December, 972-980.

U.S. Department of Commerce. 1997. Statistical Abstract of the United States: $1997\left(117^{\text {th }}\right.$ Edition). Washington D.C.: U.S. Government Printing Office.

Vandell, Dobrah L. and Janaki Ramanan. 1992. "Effects of Early and Recent Maternal Employment on Children from Low-Income Families" Child Development 63(4), August, 938-949. 


\section{Appendix}

Table A.1: Variables Used in Analysis

\begin{tabular}{|c|c|}
\hline Variable & Description \\
\hline \multicolumn{2}{|r|}{ Outcomes } \\
\hline PPVT & Peabody Picture Vocabulary Test-Revised: 3-4 year Olds \\
\hline PIAT-M & Peabody Individual. Achievement Test, Mathematics: 5-6 year olds \\
\hline PIAT-R & Peabody Individual. Achievement Test, Reading Recognition: 5-6 year olds \\
\hline \multicolumn{2}{|r|}{ Maternal Employment } \\
\hline Hours Worked & Hours worked (divided by 40 ) during specified period after giving birth \\
\hline Weeks Worked & Proportion of weeks the mother worked during specified period after giving birth \\
\hline Weeks Before & Weeks before birth of child since mother last worked \\
\hline Weeks After & Weeks after birth of child until mother began employment \\
\hline Weeks Pregnancy & Proportion of weeks worked during the 3 quarters before birth \\
\hline \multicolumn{2}{|r|}{ "Basic" Child, Maternal, and Household Characteristics (B) } \\
\hline Age & Age of child (in months) at assessment date \\
\hline Age Squared & Age Squared of child at assessment date \\
\hline Race/Ethnicity & Child is Hispanic or a non-Hispanic Black (2 d.v.'s) \\
\hline Female & Child is Female (d.v.) \\
\hline Parity & Birth order of child \\
\hline Residence & Lives in SMSA or central city at assessment date ( 2 d.v.'s) \\
\hline Mother's Age & Age (in years) of mother at the time of child's birth \\
\hline Education & Highest grade completed by mother at assessment date \\
\hline \multicolumn{2}{|r|}{ Supplemental Family and Maternal Characteristics (F) } \\
\hline Father Present & Father living in household at assessment date (d.v.) \\
\hline Married & Mother is married at survey date before pregnancy and next 3 surveys ( 4 d.v.'s) \\
\hline Divorced & $\begin{array}{l}\text { Mother is separated, divorced, or widowed at survey date before pregnancy and } \\
\text { next } 3 \text { surveys ( } 4 \text { d.v.'s) }\end{array}$ \\
\hline Poverty & Family income below poverty line in $2^{\text {nd }}$ calendar year before child's birth (d.v.) \\
\hline Siblings & Mother's number of siblings (top-coded at 15 ) \\
\hline AFQT Score & Mother's score on the Armed Forces Qualification Test in 1980 \\
\hline Foreign Born & Mother born outside the United States (d.v.) \\
\hline Foreign Language & Foreign language spoken in the mother's home at age 14 (d.v.) \\
\hline Location & Mother lived outside U.S., in Southern U.S., or in rural area at age 14 (3 d.v.'s) \\
\hline Magazines & Mother had magazines in home at age 14 (d.v.) \\
\hline Newspaper & Mother's family received a newspaper at age 14 (d.v.) \\
\hline Library Card & Someone in mother's household had a library card at age 14 (d.v.) \\
\hline Grandmother1 & Mother's mother was born outside the United States (d.v.) \\
\hline Grandmother2 & Highest grade completed by mother's mother \\
\hline Grandfather1 & Mother's father was born outside the United States (d.v.) \\
\hline Grandfather2 & Highest grade completed by mother's father \\
\hline Private & Mother's current or last secondary school attended in 1979 was private (d.v.) \\
\hline Both Parents & Mother lived with both mother and father at age 14 (d.v.) \\
\hline Mother Only & Mother lived with mother but no male in household at age 14 (d.v.) \\
\hline Siblings & Sibling born $\leq 18,19-36$ months before/after child's birth (4 d.v.'s) \\
\hline Religion & Religion was Baptist, Catholic, or no religious affiliation in 1979 (3 d.v.'s) \\
\hline
\end{tabular}


Table A.1 (Continued)

Church

First Smoked

Drug Use

Attitudes

Gestation

Birth Weight

Long Hospital Stay

Hospitalization

Doctor Visit

Prenatal Care

Alcohol

Smoker

Weight Gain

Body Mass Index
Maternal Attitudes, Religion, and Drug Use (A)

Attended church < once per week, weekly, > once per week in 1979 (3 d.v.'s)

Smoked first cigarette by $\leq 10,11-13,14-16$ years old, had not smoked by 1984 (4 d.v.'s)

Mother had tried marijuana/hashish, amphetamines/stimulants, cocaine, other drugs (barbiturates, sedatives, tranquilizers, psychedelics, heroin, other narcotics, or inhalants) by age 21 (4 d.v.'s)

Cumulative Score on 8 Family Roles Attitude Questions

\section{Pregnancy Characteristics and Child Birth Outcomes (C)}

Length of Gestation $<35,35$, or 36-37 weeks (3 d.v.'s)

Birth weight $<57,57-72,73-88$, or 89-112 ounces (4 d.v.'s)

Child stayed in hospital longer than mother following birth (d.v.)

Child was hospitalized during first year of life (d.v.)

Child visited doctor due to illness during first year of life (d.v.)

$1^{\text {st }}$ Prenatal Care in 1-2, 3-4, 5-6 month of pregnancy (3 d.v.'s)

Mother drank at least one alcoholic beverage per month during pregnancy (d.v.)

Mother smoked during pregnancy (d.v.)

Weight gain during pregnancy $<0,0-15,>50 \mathrm{lbs}$. ( 3 d.v.'s. ref. group, $16-49 \mathrm{lbs}$.)

Mother's BMI before pregnancy $<18.5,25-30,30-35,>35$ (4 d.v.'s)

Hours

Previous and Subsequent Maternal Employment Characteristics (E)

Wages

Occupation

Income

Day Care

Average weekly work hours in the $4^{\text {th }}$ quarter before birth, during pregnancy, and Year 4 (3 variables)

Day Care Mode

Hourly wages $(\$ 1996)$ in $4^{\text {th }}$ quarter prior birth were: $<\$ 5, \$ 7-\$ 7.49, \$ 7.50-\$ 10$, $\$ 10-\$ 15, \$ 15-\$ 20,>\$ 20$ (6 d.v.'s)

Occupation of main job in $4^{\text {th }}$ quarter prior to birth was: professional/technical, managerial, sales, clerical, operative, service ( 6 d.v.'s)

\section{Other Regressors}

Family income (\$1996) in calendar year before birth and next 4 years (5 variables) Child in regular nonparental care in specified year after birth First day care arrangement during specified period provided by relative, nonrelative, or in group care center/nursery school/preschool (3 d.v.'s)

\section{Paternal Variables}

Paternal Hours

Father's average weekly work hours in years 1 through 3 . Year 1 refers to the calendar year of birth (the next year) for children born before (on or after) July 1

Paternal Age Father's age in calendar year of child's birth Paternal Education Father's highest grade completed in calendar year of child's birth

Note: All variables are obtained from the NLSY. Body Mass Index is calculated using weight immediately before pregnancy and height at the 1981 interview. 


\begin{tabular}{|c|c|c|c|}
\hline Study & Data/Sample & Results & Comments \\
\hline $\begin{array}{l}\text { Baydar \& } \\
\text { Brooks- } \\
\text { Gunn } \\
(1991)\end{array}$ & $\begin{array}{l}\text { NLSY, } 572 \\
\text { white } 3-4 \\
\text { year olds (in } \\
1986 \text { ) }\end{array}$ & $\begin{array}{l}\text { Maternal employment during the first year of life } \\
\text { has negative effects on PPVT. No negative } \\
\text { effects for working in second or third year. } \\
\text { Possible positive effects for working all three } \\
\text { years. Some evidence of bigger negative effects } \\
\text { for entering work earlier in the first year. }\end{array}$ & $\begin{array}{l}\text { Other controls limited to } \\
\text { maternal AFQT score, child } \\
\text { gender, parity, poverty status. } \\
\text { Nonlinear relationship between } \\
\text { work hours in first year and } \\
\text { outcomes. }\end{array}$ \\
\hline $\begin{array}{l}\text { Blau \& } \\
\text { Grossberg } \\
\text { (1992) }\end{array}$ & $\begin{array}{l}\text { NLSY, 874 } \\
\text { 3-4 year olds } \\
\text { (in 1986) }\end{array}$ & $\begin{array}{l}\text { Maternal employment in the first (second \& } \\
\text { third) years of life associated with lower (higher) } \\
\text { PPVT scores. No net effect of working in all } \\
\text { three years. Much of second \& third year benefit } \\
\text { is due to higher incomes. Larger negative first } \\
\text { year effects for high income households. }\end{array}$ & $\begin{array}{l}\text { Controls for parent's education, } \\
\text { household incomes, } \\
\text { race/ethnicity, gender, parity, \% } \\
\text { of life in female-headed } \\
\text { household. IV models estimated, } \\
\text { but few plausible instruments. }\end{array}$ \\
\hline $\begin{array}{l}\text { Desai, } \\
\text { Chase- } \\
\text { Lansdale, } \\
\text { \& Michael } \\
(1989)\end{array}$ & $\begin{array}{l}\text { NLSY, } 5034 \\
\text { year olds (in } \\
1986 \text { ) }\end{array}$ & $\begin{array}{l}\text { Negative effect of maternal employment on } \\
\text { PPVT scores, particularly for continuous } \\
\text { employment in first } 4 \text { years. Strong negative } \\
\text { effect of continuous maternal employment and } \\
\text { job-holding in the first year for boys in high } \\
\text { income families. Possible positive effect of } \\
\text { employment beginning in the second year for } \\
\text { girls. Maternal employment negatively related to } \\
\text { fertility. More siblings and more closely spaced } \\
\text { siblings sometimes negatively related to PPVT. }\end{array}$ & $\begin{array}{l}\text { Controls for maternal } \\
\text { characteristics (age, verbal } \\
\text { ability, education, marital } \\
\text { history, race/ethnicity), } \\
\text { household income, birth order, } \\
\text { sibling age, number of day care } \\
\text { arrangements. }\end{array}$ \\
\hline $\begin{array}{l}\text { Greenstein } \\
\text { (1995) }\end{array}$ & $\begin{array}{l}\text { NLSY, } 2040 \\
4-6 \text { year olds } \\
\text { (in 1986, } \\
1988,1990)\end{array}$ & $\begin{array}{l}\text { Little relationship between maternal employment } \\
\text { and PPVT score. Interactions between maternal } \\
\text { employment and family income or cognitive } \\
\text { stimulation also insignificant. No evidence that } \\
\text { maternal employment has more detrimental } \\
\text { effects for high income households. }\end{array}$ & $\begin{array}{l}\text { Controls for child and maternal } \\
\text { characteristics and family } \\
\text { environment. Results difficult to } \\
\text { interpret because of potential } \\
\text { collinearity between regressors. }\end{array}$ \\
\hline $\begin{array}{l}\text { Harvey } \\
\text { (1999) }\end{array}$ & $\begin{array}{l}\text { NLSY, 3-12 } \\
\text { year olds in } \\
1986,1988, \\
1990,1992, \\
1994 \text { (sample } \\
\text { sizes vary) }\end{array}$ & $\begin{array}{l}\text { Negative effect of maternal work hours on PPVT } \\
\text { and PIAT scores at young ages, which weakens } \\
\text { or disappears at later ages. Some differences } \\
\text { with marital status, income, or paternal } \\
\text { employment. }\end{array}$ & $\begin{array}{l}\text { Individual, maternal, and } \\
\text { household characteristics } \\
\text { controlled for. Regressors and } \\
\text { samples vary across models } \\
\text { making the results difficult to } \\
\text { interpret, often subject to omitted } \\
\text { variables bias. }\end{array}$ \\
\hline $\begin{array}{l}\text { James- } \\
\text { Burdumy } \\
\text { (1998) }\end{array}$ & $\begin{array}{l}\text { NLSY, } 2119 \\
3-4 \text { year olds } \\
(1986,1988)\end{array}$ & $\begin{array}{l}\text { Maternal employment in first (second) year of } \\
\text { life lowers (raises) PPVT scores. The cumulative } \\
\text { effect of working in all of the first three years is } \\
\text { slightly negative. Mothers with high abilities } \\
\text { tend to work relatively few hours in first year but } \\
\text { more hours in later years. }\end{array}$ & $\begin{array}{l}\text { Controls for individual, maternal } \\
\text { and household characteristics. } \\
\text { Household fixed-effect and } \\
\text { instrumental variable techniques } \\
\text { used to control for selection bias } \\
\text { and unobserved heterogeneity. }\end{array}$ \\
\hline $\begin{array}{l}\text { Leibowitz } \\
\text { (1977) }\end{array}$ & $\begin{array}{l}\text { Sesame data, } \\
8053-5 \text { year } \\
\text { olds (in 1969) }\end{array}$ & $\begin{array}{l}\text { Full-time maternal employment negatively (but } \\
\text { not quite significantly) associated with PPVT. } \\
\text { No effect of part-time employment. Positive } \\
\text { effect of labor saving devices (dishwashers) in } \\
\text { home and of reading to children/self, but negative } \\
\text { effects of other activities. Negative relationship } \\
\text { between number of children \& PPVT. }\end{array}$ & $\begin{array}{l}\text { Controls for parent's education, } \\
\text { race/ethnicity, native language, } \\
\text { home environment, day care } \\
\text { arrangements, number of } \\
\text { children. }\end{array}$ \\
\hline
\end{tabular}




\begin{tabular}{|c|c|c|c|}
\hline $\begin{array}{l}\text { Moore \& } \\
\text { Driscoll } \\
\text { (1997) }\end{array}$ & $\begin{array}{l}\text { NLSY, } 1154 \\
5-14 \text { year } \\
\text { olds }(1992) \\
\text { mothers on } \\
\text { AFDC during } \\
\text { 1986-1990 }\end{array}$ & $\begin{array}{l}\text { Maternal employment in } 1991 \text { associated with } \\
\text { higher PIAT Reading and Math scores. Most } \\
\text { effects eliminated after controlling for child, } \\
\text { maternal, \& household characteristics, although } \\
\text { behavioral problems and higher math scores } \\
\text { persist for daughters of higher earning women. }\end{array}$ & $\begin{array}{l}\text { Controls for sex, age, birth order, } \\
\text { health, birth weight, maternal } \\
\text { characteristics \& attitudes, } \\
\text { family employment \& AFDC } \\
\text { history. Omitted variable bias } \\
\text { probably persists and may } \\
\text { explain benefits of working. }\end{array}$ \\
\hline $\begin{array}{l}\text { Mott } \\
(1991)\end{array}$ & $\begin{array}{l}\text { NLSY, } 2387 \\
1-4 \text { year olds } \\
\text { (in 1986) }\end{array}$ & $\begin{array}{l}\text { Maternal employment averaging more than } 20 \\
\text { hours per week in second quarter of child's life } \\
\text { negatively related to PPVT scores (ages 3-4); no } \\
\text { effect on MFL scores (ages 1-3). No effect of } \\
\text { lower work hours. Employment in first quarter } \\
\text { insignificantly negatively related to MFL scores. }\end{array}$ & $\begin{array}{l}\text { Comprehensive controls for } \\
\text { child \& family characteristics } \\
\text { including early health problems } \\
\text { and substance use during } \\
\text { pregnancy. Collinearity between } \\
\text { maternal employment and child } \\
\text { care arrangements makes results } \\
\text { difficult to interpret. }\end{array}$ \\
\hline $\begin{array}{l}\text { Parcel \& } \\
\text { Menaghan } \\
\text { (1994) }\end{array}$ & $\begin{array}{l}\text { NLSY, } 768 \\
3-6 \text { year olds } \\
\text { with } \\
\text { employed } \\
\text { mothers (in } \\
\text { 1986) }\end{array}$ & $\begin{array}{l}\text { Maternal employment during the first year or first } \\
\text { three years positively correlated with PPVT } \\
\text { scores. Effect is not monotonic in work hours. } \\
\text { Subsequent full-time maternal work correlated } \\
\text { with higher PPVT, compared to working part- } \\
\text { time. Early (current) full-time paternal } \\
\text { employment associated with insignificantly lower } \\
\text { (higher) PPVT scores. Some evidence that } \\
\text { maternal employment is more problematic for } \\
\text { less well-off women. }\end{array}$ & $\begin{array}{l}\text { Comprehensive controls for } \\
\text { child and parent characteristics, } \\
\text { the home environment, and } \\
\text { working conditions. Results are } \\
\text { difficult to interpret because of } \\
\text { potential endogeneity (e.g. home } \\
\text { environment and work hours) } \\
\text { and collinearity (e.g. wage, } \\
\text { occupational complexity, and } \\
\text { work hours) of regressors. }\end{array}$ \\
\hline $\begin{array}{l}\text { Stafford } \\
\text { (1987) }\end{array}$ & $\begin{array}{l}\text { SRC Time } \\
\text { Use Study, } 77 \\
\text { elem. school } \\
\text { students (in } \\
\text { 1981/2) }\end{array}$ & $\begin{array}{l}\text { Cognitive skills (measured by } 7 \text { indicators and a } \\
\text { composite) fall with the number of siblings } \\
\text { (particularly males), rise with family income, and } \\
\text { decline with mother's market work hours in the } \\
\text { pre-school years. }\end{array}$ & $\begin{array}{l}\text { Detailed teacher evaluations of } \\
\text { cognitive development. } \\
\text { Maternal employment refers to } \\
\text { various ages prior to start of } \\
\text { school. }\end{array}$ \\
\hline $\begin{array}{l}\text { Vandell \& } \\
\text { Ramanan } \\
\text { (1992) }\end{array}$ & $\begin{array}{l}\text { NLSY, } 189 \\
\text { low income } \\
\text { non-Hispanic } \\
\text { second- } \\
\text { graders (in } \\
\text { 1986) }\end{array}$ & $\begin{array}{l}\text { Maternal employment in first three years (and } \\
\text { subsequently) positively correlated with the } \\
\text { mothers' education, AFQT score, family income, } \\
\text { and quality of home environment. Employment } \\
\text { in first three years correlated with higher PIAT- } \\
\text { math and insignificantly lower PPVT scores. } \\
\text { Recent employment correlated with higher PIAT- } \\
\text { reading and PPVT scores. }\end{array}$ & $\begin{array}{l}\text { Controls for the child's race, } \\
\text { gender; mother's age, education, } \\
\text { marital status, family income, } \\
\text { attitudes, AFQT and Rosenberg } \\
\text { self-esteem scores, and HOME } \\
\text { scale. Sample selection criteria } \\
\text { is not specified. }\end{array}$ \\
\hline
\end{tabular}

Notes: Abbreviations: NLSY: National Longitudinal Survey of Youth; SRC: Survey Research Center; MFL: Memory for Location score; PIAT: Peabody Individual Achievement Test; PPVT: Peabody Picture Vocabulary Test. 
Table 2: Sample Means of Selected Variables By Average

Weekly Work Hours of Mother in Specified Periods

\begin{tabular}{|c|c|c|c|c|c|c|c|}
\hline \multirow[t]{2}{*}{ Variable } & \multirow{2}{*}{$\begin{array}{c}\text { Full } \\
\text { Sample }\end{array}$} & \multicolumn{3}{|c|}{$\begin{array}{l}\text { Work Hours } \\
\text { During Year } 1\end{array}$} & \multicolumn{3}{|c|}{$\begin{array}{c}\text { Work Hours } \\
\text { During Years } 2 \text { and } 3\end{array}$} \\
\hline & & $\mathbf{0}$ & $1-29$ & $\geq \mathbf{3 0}$ & $\mathbf{0}$ & $1-29$ & $\geq \mathbf{3 0}$ \\
\hline \multicolumn{8}{|l|}{ Outcomes } \\
\hline PPVT & $\begin{array}{c}92.2 \\
{[20.0]}\end{array}$ & $\begin{array}{l}89.2 \\
(0.8)\end{array}$ & $\begin{array}{l}94.0 \\
(0.6)\end{array}$ & $\begin{array}{l}94.1 \\
(0.8)\end{array}$ & $\begin{array}{l}87.9 \\
(1.0)\end{array}$ & $\begin{array}{l}93.7 \\
(0.6)\end{array}$ & $\begin{array}{r}93.5 \\
(0.7)\end{array}$ \\
\hline PIAT-R & $\begin{array}{l}105.5 \\
{[13.4]}\end{array}$ & $\begin{array}{l}104.2 \\
(0.4)\end{array}$ & $\begin{array}{l}106.0 \\
(0.4)\end{array}$ & $\begin{array}{l}107.0 \\
(0.5)\end{array}$ & $\begin{array}{l}103.3 \\
(0.5)\end{array}$ & $\begin{array}{l}105.9 \\
(0.4)\end{array}$ & $\begin{array}{l}106.8 \\
(0.5)\end{array}$ \\
\hline PIAT-M & $\begin{array}{l}101.0 \\
{[13.8]}\end{array}$ & $\begin{array}{l}99.5 \\
(0.4)\end{array}$ & $\begin{array}{l}101.7 \\
(0.4)\end{array}$ & $\begin{array}{l}102.5 \\
(0.5)\end{array}$ & $\begin{array}{l}98.7 \\
(0.5)\end{array}$ & $\begin{array}{l}101.6 \\
(0.4)\end{array}$ & $\begin{array}{l}102.0 \\
(0.5)\end{array}$ \\
\hline \multicolumn{8}{|l|}{ Selected Regressors } \\
\hline $\begin{array}{l}\text { Mother's Age at Birth } \\
\text { (in years) }\end{array}$ & 24.7 & $\begin{array}{l}24.3 \\
(0.1)\end{array}$ & $\begin{array}{l}24.4 \\
(0.1)\end{array}$ & $\begin{array}{l}25.9 \\
(0.1)\end{array}$ & $\begin{array}{l}24.8 \\
(0.1)\end{array}$ & $\begin{array}{l}24.1 \\
(0.1)\end{array}$ & $\begin{array}{l}25.6 \\
(0.1)\end{array}$ \\
\hline Mother's AFQT Score & 67.9 & $\begin{array}{l}61.9 \\
(0.6)\end{array}$ & $\begin{array}{l}70.6 \\
(0.6)\end{array}$ & $\begin{array}{l}73.8 \\
(0.7)\end{array}$ & $\begin{array}{l}61.5 \\
(0.8)\end{array}$ & $\begin{array}{l}68.4 \\
(0.6)\end{array}$ & $\begin{array}{l}72.6 \\
(0.6)\end{array}$ \\
\hline $\begin{array}{l}\text { Mother's Education } \\
\text { (in years) }\end{array}$ & 12.5 & $\begin{array}{l}12.0 \\
(0.1)\end{array}$ & $\begin{array}{l}12.6 \\
(0.1)\end{array}$ & $\begin{array}{l}13.2 \\
(0.1)\end{array}$ & $\begin{array}{l}12.0 \\
(0.1)\end{array}$ & $\begin{array}{l}12.4 \\
(0.1)\end{array}$ & $\begin{array}{l}13.1 \\
(0.1)\end{array}$ \\
\hline $\begin{array}{l}\text { Family in Poverty in } 2^{\text {nd }} \\
\text { Year Before Birth }(\%)\end{array}$ & 18.8 & $\begin{array}{l}29.9 \\
(1.3)\end{array}$ & $\begin{array}{l}14.4 \\
(1.2)\end{array}$ & $\begin{array}{c}6.3 \\
(0.9)\end{array}$ & $\begin{array}{l}31.2 \\
(1.7)\end{array}$ & $\begin{array}{l}18.5 \\
(1.1)\end{array}$ & $\begin{array}{c}8.4 \\
(0.1)\end{array}$ \\
\hline Low Birth Weight (\%) & 6.5 & $\begin{array}{c}7.7 \\
(0.7)\end{array}$ & $\begin{array}{c}5.8 \\
(0.7)\end{array}$ & $\begin{array}{c}5.5 \\
(0.9)\end{array}$ & $\begin{array}{c}8.6 \\
(0.9)\end{array}$ & $\begin{array}{c}5.4 \\
(0.6)\end{array}$ & $\begin{array}{c}6.2 \\
(0.8)\end{array}$ \\
\hline
\end{tabular}

Notes: Table displays averages for the nationally representative subsample of the NLSY. Year 1 refers to the first 4 quarters after birth; years 2 and 3 to the fifth through twelfth quarters after birth. Standard deviations are in brackets; standard errors are in parentheses. The PPVT, PIAT$\mathrm{R}$ and PIAT-M indicate standard scores on the Peabody Picture Vocabulary Test-Revised, and the Peabody Individual Achievement Reading Recognition and Mathematics Subtests. The sample for these tests are 5-6 year (60-83 month) old children, except for the PPVT, where 3-4 year (36-59 month) old children are assessed. Mother's education is measured at the time her child is 5 or 6 years old. Low birth weight indicates that the child weighed less than 5.5 pounds at birth. 
Table 3:

Regression Estimates of the Effects of Maternal Employment on Child Cognitive Development

\begin{tabular}{|c|c|c|c|c|c|c|c|c|c|c|}
\hline Time Period & (a) & (b) & (c) & (d) & (e) & (f) & (g) & (h) & (i) & (j) \\
\hline \multicolumn{11}{|c|}{ PPVT Score } \\
\hline Year 1 & $\begin{array}{c}.099 \\
(.057)\end{array}$ & $\begin{array}{l}-.083 \\
(.048)\end{array}$ & $\begin{array}{l}-.080 \\
(.046)\end{array}$ & $\begin{array}{l}-.076 \\
(.046)\end{array}$ & $\begin{array}{l}-.078 \\
(.046)\end{array}$ & $\begin{array}{l}-.130 \\
(.054)\end{array}$ & $\begin{array}{l}-.129 \\
(.054)\end{array}$ & $\begin{array}{l}-.110 \\
(.052)\end{array}$ & $\begin{array}{l}-.182 \\
(.054)\end{array}$ & $\begin{array}{l}-.131 \\
(.048)\end{array}$ \\
\hline Years 2 and 3 & $\begin{array}{c}.205 \\
(.054)\end{array}$ & $\begin{array}{c}.120 \\
(.045)\end{array}$ & $\begin{array}{c}.034 \\
(.045)\end{array}$ & $\begin{array}{c}.043 \\
(.045)\end{array}$ & $\begin{array}{c}.049 \\
(.045)\end{array}$ & $\begin{array}{l}.063 \\
(.055)\end{array}$ & $\begin{array}{l}.058 \\
(.055)\end{array}$ & $\begin{array}{c}.052 \\
(.055)\end{array}$ & $\begin{array}{l}.052 \\
(.055)\end{array}$ & $\begin{array}{c}.042 \\
(.049)\end{array}$ \\
\hline \multicolumn{11}{|c|}{ PIAT-R Score } \\
\hline Year 1 & $\begin{array}{c}.168 \\
(.054)\end{array}$ & $\begin{array}{c}.028 \\
(.050)\end{array}$ & $\begin{array}{l}-.004 \\
(.049)\end{array}$ & $\begin{array}{c}.004 \\
(.049)\end{array}$ & $\begin{array}{c}.013 \\
(.049)\end{array}$ & $\begin{array}{l}-.085 \\
(.058)\end{array}$ & $\begin{array}{l}-.086 \\
(.058)\end{array}$ & $\begin{array}{l}-.125 \\
(.055)\end{array}$ & $\begin{array}{l}-.082 \\
(.058)\end{array}$ & $\begin{array}{l}-.092 \\
(.051)\end{array}$ \\
\hline Years 2 and 3 & $\begin{array}{l}.125 \\
(.051)\end{array}$ & $\begin{array}{l}-.009 \\
(.047)\end{array}$ & $\begin{array}{l}-.069 \\
(.047)\end{array}$ & $\begin{array}{l}-.070 \\
(.047)\end{array}$ & $\begin{array}{l}-.080 \\
(.047)\end{array}$ & $\begin{array}{l}-.151 \\
(.058)\end{array}$ & $\begin{array}{l}-.149 \\
(.058)\end{array}$ & $\begin{array}{l}-.115 \\
(.058)\end{array}$ & $\begin{array}{l}-.141 \\
(.058)\end{array}$ & $\begin{array}{l}-.120 \\
(.051)\end{array}$ \\
\hline \multicolumn{11}{|c|}{ PIAT-M Score } \\
\hline Year 1 & $\begin{array}{l}.159 \\
(.054)\end{array}$ & $\begin{array}{c}.034 \\
(.050)\end{array}$ & $\begin{array}{l}.016 \\
(.050)\end{array}$ & $\begin{array}{c}.020 \\
(.050)\end{array}$ & $\begin{array}{c}.019 \\
(.050)\end{array}$ & $\begin{array}{l}-.036 \\
(.059)\end{array}$ & $\begin{array}{l}-.041 \\
(.060)\end{array}$ & $\begin{array}{l}-.036 \\
(.056)\end{array}$ & $\begin{array}{l}-.042 \\
(.059)\end{array}$ & $\begin{array}{l}-.050 \\
(.053)\end{array}$ \\
\hline Years 2 and 3 & $\begin{array}{l}.088 \\
(.051)\end{array}$ & $\begin{array}{c}.004 \\
(.047)\end{array}$ & $\begin{array}{l}-.061 \\
(.048)\end{array}$ & $\begin{array}{l}-.064 \\
(.048)\end{array}$ & $\begin{array}{l}-.065 \\
(.048)\end{array}$ & $\begin{array}{l}-.119 \\
(.060)\end{array}$ & $\begin{array}{l}-.118 \\
(.060)\end{array}$ & $\begin{array}{l}-.127 \\
(.059)\end{array}$ & $\begin{array}{l}-.125 \\
(.060)\end{array}$ & $\begin{array}{l}-.096 \\
(.053)\end{array}$ \\
\hline $\begin{array}{l}\text { Additional } \\
\text { Regressors }\end{array}$ & None & $\mathrm{B}$ & $\mathrm{B}, \mathrm{F}$ & $\mathrm{B}, \mathrm{F}, \mathrm{A}$ & $\mathrm{B}, \mathrm{F}, \mathrm{A}, \mathrm{C}$ & $\begin{array}{c}\mathrm{B}, \mathrm{F}, \mathrm{A} \\
\mathrm{C}, \mathrm{E}\end{array}$ & $\begin{array}{c}\text { B,F,A, } \\
\text { C,E,I }\end{array}$ & $\begin{array}{c}\mathrm{B}, \mathrm{F}, \mathrm{A} \\
\mathrm{C}, \mathrm{E}\end{array}$ & $\begin{array}{c}\mathrm{B}, \mathrm{F}, \mathrm{A} \\
\mathrm{C}, \mathrm{E}\end{array}$ & $\begin{array}{c}\mathrm{B}, \mathrm{F}, \mathrm{A} \\
\mathrm{C}, \mathrm{E}\end{array}$ \\
\hline $\begin{array}{l}\text { Dependent } \\
\text { Variable }\end{array}$ & $\begin{array}{c}\text { Standard } \\
\text { Score }\end{array}$ & $\begin{array}{c}\text { Standard } \\
\text { Score }\end{array}$ & $\begin{array}{c}\text { Standard } \\
\text { Score }\end{array}$ & $\begin{array}{c}\text { Standard } \\
\text { Score }\end{array}$ & $\begin{array}{c}\text { Standard } \\
\text { Score }\end{array}$ & $\begin{array}{c}\text { Standard } \\
\text { Score }\end{array}$ & $\begin{array}{c}\text { Standard } \\
\text { Score }\end{array}$ & $\begin{array}{c}\text { Standard } \\
\text { Score }\end{array}$ & $\begin{array}{l}\text { Percentile } \\
\text { Score }\end{array}$ & $\begin{array}{l}\text { Raw } \\
\text { Score }\end{array}$ \\
\hline $\begin{array}{l}\text { Employment } \\
\text { Variable }\end{array}$ & Hours & Hours & Hours & Hours & Hours & Hours & Hours & Weeks & Hours & Hours \\
\hline
\end{tabular}


Notes: The table shows coefficients for OLS regressions of the specified assessment score, normalized to have a standard deviation of 1. Standard errors are shown in parentheses. PPVT scores are measured for children 36-59 months of age; PIAT scores for those aged 60-83 months. "Standard" scores are used in all specifications except columns (i) and (j), where percentile and raw scores are utilized. "Hours" indicate average weekly work hours divided by 40. "Weeks" refers to the proportion of weeks worked during the specified period. Year 1 includes the first four quarters after birth; years 2 and 3 refer to the fifth through twelfth quarters after birth. All models control for the assessment year. The categories of additional regressors are "Basic" Child, Maternal, and Household Characteristics (B); Supplemental Family and Maternal Characteristics (F); Maternal Attitudes, Religion, and Drug Use (A);

Pregnancy Characteristics and Child Birth Outcomes (C), Previous and Subsequent Maternal Employment Characteristics (E), and Family Incomes (I) in the calendar year before birth and the next 4 years. Full descriptions are provided in Table A.1 Sample sizes in the hours equations range between 4200 and 4213 for PPVT scores, 4716 to 4729 for the PIAT-R, and 4875 to 4838 for the PIAT-M assessment. 
Table 4: Alternative Regression Estimates of the Effects of Maternal Employment

\begin{tabular}{lccc}
\hline Time Period & PPVT & PIAT-R & PIAT-M \\
\hline Year 1 & -.147 & -.064 & .057 \\
& $(.057)$ & $(.060)$ & $(.061)$ \\
Year 2 & .050 & -.132 & -.004 \\
& $(.055)$ & $(.056)$ & $(.058)$ \\
Year 3 & .013 & -.019 & -.116 \\
& $(.054)$ & $(.057)$ & $(.058)$ \\
\hline & & & .019 \\
Year $\mathbf{1}$ & -.114 & -.063 & $(.067)$ \\
& $(.062)$ & $(.066)$ & -.001 \\
Years $\mathbf{2}$ and 3 if Hours in & .095 & -.106 & $(.090)$ \\
$\quad$ Year $\mathbf{1}=\mathbf{0}$ & $(.083)$ & $(.088)$ & -.161 \\
Years $\mathbf{2}$ and 3 if Hours in & .051 & -.167 & $(.064)$ \\
$\quad$ Year $\mathbf{1}>\mathbf{0}$ & $(.060)$ & $(.063)$ & \\
\hline
\end{tabular}

Notes: See notes on Table 3. The models control for the same variables as specification (f) of that table, except that the effects of maternal employment are separately estimated for years 2 and 3 in the top panel; in the bottom panel, the effects of maternal employment in years 2 and 3 are allowed to differ depending on whether or not the mother worked in year 1. 
Table 5: Regression Estimates of the Overall Effect of Maternal Employment During the First Three Years For Alternative Groups of Children

\begin{tabular}{|c|c|c|c|}
\hline Group & PPVT & PIAT-R & PIAT-M \\
\hline Full Sample & $\begin{array}{c}-.044 \\
(.056)\end{array}$ & $\begin{array}{c}-.234 \\
(.060)\end{array}$ & $\begin{array}{l}-.159 \\
(.061)\end{array}$ \\
\hline First-Born Children & $\begin{array}{c}-.097 \\
(.078)\end{array}$ & $\begin{array}{c}-.229 \\
(.090)\end{array}$ & $\begin{array}{c}-.121 \\
(.090)\end{array}$ \\
\hline Father Present & $\begin{array}{c}-.081 \\
(.067)\end{array}$ & $\begin{array}{c}-.186 \\
(.073)\end{array}$ & $\begin{array}{c}-.211 \\
(.074)\end{array}$ \\
\hline Father Not Present & $\begin{array}{c}.098 \\
(.112)\end{array}$ & $\begin{array}{l}-.236 \\
(.113)\end{array}$ & $\begin{array}{c}-.022 \\
(.119)\end{array}$ \\
\hline Spouse Present & $\begin{array}{c}-.089 \\
(.072)\end{array}$ & $\begin{array}{c}-.205 \\
(.079)\end{array}$ & $\begin{array}{c}-.096 \\
(.079)\end{array}$ \\
\hline Spouse Not Present & $\begin{array}{c}.251 \\
(.125)\end{array}$ & $\begin{array}{l}-.061 \\
(.126)\end{array}$ & $\begin{array}{c}.095 \\
(.138)\end{array}$ \\
\hline Wage $\geq \$ 10 /$ hour & $\begin{array}{l}-.162 \\
(.125)\end{array}$ & $\begin{array}{l}-.206 \\
(.142)\end{array}$ & $\begin{array}{c}-.087 \\
(.142)\end{array}$ \\
\hline Wage $<\$ 10 /$ hour & $\begin{array}{c}.016 \\
(.075)\end{array}$ & $\begin{array}{l}-.223 \\
(.085)\end{array}$ & $\begin{array}{l}-.110 \\
(.086)\end{array}$ \\
\hline
\end{tabular}

Notes: See notes on Table 3. This table shows coefficients on average weekly work hours during the first three years of the child's life. These are obtained from models controlling for the same variables as specification (f) of Table 3. The second panel limits the analysis to first-born children. The third divides the sample by whether the child's father lives in the household on the survey date of the fourth calendar year following the birth. The first row of the fourth panel is restricted to children whose mothers have a spouse in the household at each of the survey dates in the first three calendar years following birth. The second row refers to those whose mothers do not have a spouse living in the household at any of the three survey dates. The fifth panel stratifies the sample by the hourly wage (in \$1996) of the mother in the fourth quarter prior to the child's birth; this analysis is restricted to women reporting wages. 


\begin{tabular}{|c|c|c|c|}
\hline & \multicolumn{3}{|c|}{ Time Period } \\
\hline & $\underline{\text { Year } 1}$ & $\underline{\text { Year } 2}$ & $\underline{\text { Year } 3}$ \\
\hline Day Care Used & $\begin{array}{l}43.7 \% \\
(0.9)\end{array}$ & $\begin{array}{l}49.9 \% \\
(0.9)\end{array}$ & $\begin{array}{l}54.1 \% \\
(0.9)\end{array}$ \\
\hline Multiple Day Care Arrangements & $\begin{array}{c}9.2 \\
(0.5)\end{array}$ & $\begin{array}{c}8.8 \\
(0.5)\end{array}$ & $\begin{array}{c}8.4 \\
(0.5)\end{array}$ \\
\hline Day Care by Relative & $\begin{array}{l}19.7 \\
(0.7)\end{array}$ & $\begin{array}{l}20.1 \\
(0.7)\end{array}$ & $\begin{array}{l}18.2 \\
(0.7)\end{array}$ \\
\hline Day Care by Nonrelative & $\begin{array}{l}15.7 \\
(0.6)\end{array}$ & $\begin{array}{l}16.8 \\
(0.6)\end{array}$ & $\begin{array}{l}14.6 \\
(0.6)\end{array}$ \\
\hline Day Care in Mother's Home & $\begin{array}{l}11.0 \\
(0.5)\end{array}$ & $\begin{array}{l}11.1 \\
(0.5)\end{array}$ & $\begin{array}{l}10.9 \\
(0.5)\end{array}$ \\
\hline \multirow[t]{3}{*}{ Day Care in Center or Preschool } & $\begin{array}{c}4.5 \\
(0.4)\end{array}$ & $\begin{array}{c}9.5 \\
(0.5)\end{array}$ & $\begin{array}{l}15.1 \\
(0.6)\end{array}$ \\
\hline & \multicolumn{3}{|c|}{ Weekly Work Hours in Specified Period } \\
\hline & \multicolumn{2}{|c|}{ Day Care Used } & $\geq \underline{\mathbf{3 0}}$ \\
\hline Year 1 & $\begin{array}{l}13.0 \% \\
(0.9)\end{array}$ & $\begin{array}{l}50.3 \% \\
(1.4)\end{array}$ & $\begin{array}{l}87.6 \% \\
(1.2)\end{array}$ \\
\hline Year 2 & $\begin{array}{l}16.7 \\
(1.1)\end{array}$ & $\begin{array}{l}51.7 \\
(1.3)\end{array}$ & $\begin{array}{l}86.6 \\
(1.1)\end{array}$ \\
\hline Year 3 & $\begin{array}{l}20.2 \\
(1.2)\end{array}$ & $\begin{array}{l}57.2 \\
(1.5)\end{array}$ & $\begin{array}{l}85.9 \\
(1.1)\end{array}$ \\
\hline \multicolumn{4}{|l|}{ Day Care in Center or Preschool } \\
\hline Year 1 & $\begin{array}{l}0.8 \% \\
(0.2)\end{array}$ & $\begin{array}{l}4.9 \% \\
(0.6)\end{array}$ & $\begin{array}{l}10.3 \% \\
(1.1)\end{array}$ \\
\hline Year 2 & $\begin{array}{c}4.3 \\
(0.6)\end{array}$ & $\begin{array}{c}9.1 \\
(0.8)\end{array}$ & $\begin{array}{l}16.1 \\
(1.2)\end{array}$ \\
\hline Year 3 & $\begin{array}{c}6.1 \\
(0.7)\end{array}$ & $\begin{array}{l}14.8 \\
(1.1)\end{array}$ & $\begin{array}{l}24.8 \\
(1.3)\end{array}$ \\
\hline
\end{tabular}

Note: Table displays percentages of children in each category for the national representative subsample of the NLSY. Standard errors are in parentheses. The top panel shows cell percentages for all children in the specified age group. The bottom sample stratifies by average weekly work hours of the mother in the year corresponding to that in which the child care is received. The particular types of day care refer to the first arrangement in the specified year. 
Table 7: Estimated Effect of Maternal Employment on Child Assessment Scores Under Different Child Care Arrangements

\begin{tabular}{|c|c|c|c|c|c|c|}
\hline \multirow{2}{*}{ Regressor } & \multicolumn{2}{|c|}{ PPVT } & \multicolumn{2}{|c|}{ PIAT-R } & \multicolumn{2}{|c|}{ PIAT-M } \\
\hline & (a) & (b) & (a) & (b) & (a) & (b) \\
\hline \multicolumn{7}{|l|}{ Year 1} \\
\hline Work Hours & $\begin{array}{c}-.092 \\
(.074)\end{array}$ & $\begin{array}{c}-.096 \\
(.074)\end{array}$ & $\begin{array}{l}-.111 \\
(.077)\end{array}$ & $\begin{array}{c}-.122 \\
(.077)\end{array}$ & $\begin{array}{c}-.070 \\
(.079)\end{array}$ & $\begin{array}{c}-.076 \\
(.079)\end{array}$ \\
\hline Hours x Day Care & $\begin{array}{c}-.053 \\
(.065)\end{array}$ & & $\begin{array}{c}.036 \\
(.070)\end{array}$ & & $\begin{array}{c}.039 \\
(.071)\end{array}$ & \\
\hline Hours x Relative Care & & $\begin{array}{c}.005 \\
(.073)\end{array}$ & & $\begin{array}{c}.066 \\
(.078)\end{array}$ & & $\begin{array}{l}.106 \\
(.079)\end{array}$ \\
\hline Hours x Center Care & & $\begin{array}{l}-.126 \\
(.102)\end{array}$ & & $\begin{array}{c}-.043 \\
(.109)\end{array}$ & & $\begin{array}{l}-.127 \\
(.112)\end{array}$ \\
\hline Hours x Other Care & & $\begin{array}{l}-.097 \\
(.074)\end{array}$ & & $\begin{array}{c}.043 \\
(.080)\end{array}$ & & $\begin{array}{c}.011 \\
(.082)\end{array}$ \\
\hline \multicolumn{7}{|l|}{ Years 2 and 3} \\
\hline Work Hours & $\begin{array}{c}.016 \\
(.084)\end{array}$ & $\begin{array}{c}.020 \\
(.084)\end{array}$ & $\begin{array}{l}-.144 \\
(.085)\end{array}$ & $\begin{array}{l}-.139 \\
(.085)\end{array}$ & $\begin{array}{c}-.175 \\
(.086)\end{array}$ & $\begin{array}{c}-.172 \\
(.086)\end{array}$ \\
\hline Hours x Day Care & $\begin{array}{c}.057 \\
(.075)\end{array}$ & & $\begin{array}{l}-.012 \\
(.076)\end{array}$ & & $\begin{array}{c}.065 \\
(.077)\end{array}$ & \\
\hline Hours x Relative Care & & $\begin{array}{c}.047 \\
(.080)\end{array}$ & & $\begin{array}{l}-.062 \\
(.081)\end{array}$ & & $\begin{array}{c}.039 \\
(.082)\end{array}$ \\
\hline Hours x Center Care & & $\begin{array}{l}.130 \\
(.086)\end{array}$ & & $\begin{array}{c}.095 \\
(.088)\end{array}$ & & $\begin{array}{c}.131 \\
(.089)\end{array}$ \\
\hline Hours $x$ Other Care & & $\begin{array}{c}.022 \\
(.084)\end{array}$ & & $\begin{array}{l}-.015 \\
(.086)\end{array}$ & & $\begin{array}{c}.054 \\
(.087)\end{array}$ \\
\hline
\end{tabular}

Note: See note on Table 3. This table shows regression coefficients for interactions between average weekly work hours (divided by 40 ) and the specified type of day care. Standard errors are in parentheses. These estimates are obtained from models that otherwise correspond to specification (f) of Table 3. Child care type indicates the first arrangement during the period. Center care in years 2 and 3 refers to children whose first arrangement is in a center during one of these years and who are not cared for by a relative (as the first arrangement) in either year. 
Table 8: Effects of Maternal and Paternal Employment During the First three years on Child Assessment Scores

Parental
Employment

\section{Full Sample}

(b)

(a)

Mother

\section{Mother}

Father

$\begin{array}{cccc}-.042 & -.037 & -.031 & -.035 \\ (.074) & (.074) & (.074) & (.074) \\ & .182 & .163 & .054 \\ & (.060) & (.067) & (.085)\end{array}$

PIAT-R Score

\begin{tabular}{|c|c|c|c|c|c|c|c|c|}
\hline & & $(.000)$ & $(.00 /)$ & $(.085)$ & $(.088)$ & $(.090)$ & $(.100)$ & $(.100)$ \\
\hline \multicolumn{9}{|c|}{ PIAT-R Score } \\
\hline Mother & $\begin{array}{l}-.170 \\
(.084)\end{array}$ & $\begin{array}{l}-.168 \\
(.084)\end{array}$ & $\begin{array}{l}-.149 \\
(.084)\end{array}$ & $\begin{array}{l}-.152 \\
(.084)\end{array}$ & $\begin{array}{l}-.192 \\
(.089)\end{array}$ & $\begin{array}{l}-.195 \\
(.089)\end{array}$ & $\begin{array}{l}-.229 \\
(.098)\end{array}$ & $\begin{array}{l}-.229 \\
(.098)\end{array}$ \\
\hline Father & & $\begin{array}{l}.072 \\
(.067)\end{array}$ & $\begin{array}{l}.030 \\
(.076)\end{array}$ & $\begin{array}{l}-.166 \\
(.096)\end{array}$ & $\begin{array}{l}-.086 \\
(.103)\end{array}$ & $\begin{array}{l}-.188 \\
(.106)\end{array}$ & $\begin{array}{l}-.158 \\
(.117)\end{array}$ & $\begin{array}{l}-.171 \\
(.117)\end{array}$ \\
\hline \multicolumn{9}{|c|}{ PIAT-M Score } \\
\hline Mother & $\begin{array}{l}-.145 \\
(.083)\end{array}$ & $\begin{array}{l}-.143 \\
(.083)\end{array}$ & $\begin{array}{l}-.129 \\
(.083)\end{array}$ & $\begin{array}{l}-.127 \\
(.083)\end{array}$ & $\begin{array}{l}-.139 \\
(.089)\end{array}$ & $\begin{array}{l}-.139 \\
(.089)\end{array}$ & $\begin{array}{l}-.142 \\
(.098)\end{array}$ & $\begin{array}{l}-.141 \\
(.098)\end{array}$ \\
\hline Father & & $\begin{array}{l}.086 \\
(.066)\end{array}$ & $\begin{array}{l}.085 \\
(.075)\end{array}$ & $\begin{array}{l}.035 \\
(.096)\end{array}$ & $\begin{array}{l}-.006 \\
(.103)\end{array}$ & $\begin{array}{l}-.016 \\
(.105)\end{array}$ & $\begin{array}{l}-.094 \\
(.117)\end{array}$ & $\begin{array}{l}-.073 \\
(.117)\end{array}$ \\
\hline $\begin{array}{l}\text { Paternal } \\
\text { Characteristics }\end{array}$ & No & No & Yes & Yes & Yes & Yes & Yes & Yes \\
\hline $\begin{array}{l}\text { Averaging of } \\
\text { Paternal Hours }\end{array}$ & & $\begin{array}{c}\text { All } \\
\text { Weeks }\end{array}$ & $\begin{array}{c}\text { All } \\
\text { Weeks }\end{array}$ & $\begin{array}{l}\text { Weeks } \\
\text { Worked }\end{array}$ & $\begin{array}{c}\text { All } \\
\text { Weeks }\end{array}$ & $\begin{array}{l}\text { Weeks } \\
\text { Worked }\end{array}$ & $\begin{array}{c}\text { All } \\
\text { Weeks }\end{array}$ & $\begin{array}{l}\text { Weeks } \\
\text { Worked }\end{array}$ \\
\hline
\end{tabular}

Weeks Father Works In Years 1-3:

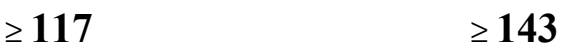

(e) $\quad$ (f) $\quad$ (g)

$\begin{array}{llll}-.013 & -.013 & -.057 & -.057\end{array}$

$\begin{array}{llll}(.075) & (.075) & (.083) & (.083)\end{array}$

$\begin{array}{llll}-.016 & -.022 & -.019 & -.029\end{array}$

$\begin{array}{llll}(.088) & (.090) \quad(.100) & (.100)\end{array}$ 
Notes: See note on Tables 3. The models control for the same regressors as specification (f) of that table, except that maternal employment is averaged over the first three years. Columns (b) through (h) also hold constant the father's average weekly work hours (divided by 40) in the first three years. The sample is limited to children whose father resided in the mother's household on the survey date of the fourth calendar year following the birth and for whom information on paternal employment are available in all three years. Columns (c) through (h) also control for the fathers age and number of years of schooling in the calendar year of the child's birth, as well as average hours of work in weeks of employment in year 4. Models (e) and (f) further restrict the sample to children whose fathers worked at least 117 weeks during the three years; specifications $(\mathrm{g})$ and $(\mathrm{h})$ to those whose fathers were employed 143 or more weeks. Fathers work hours during the first three years are averaged over all weeks in specifications (a) through (c), (e), and (g). They are averaged over weeks of employment only in columns (d), (f), and (h). The latter "conditional" estimates, exclude children whose fathers were never employed during the first three years. Sample sizes are 2324, 2462, and 2523 for PPVT, PIAT-R, and PIAT-M scores for the full sample For the corresponding conditional estimates they are 2308, 2444, and 2505. Sizes of the subsample with fathers working at least 117 weeks are 2044, 2150, and 2203, and for those with fathers employed 143 weeks or more they are 1752, 1840 , and 1886. 
Fig. 1: Weeks Worked By Mothers Before and After Child Birth
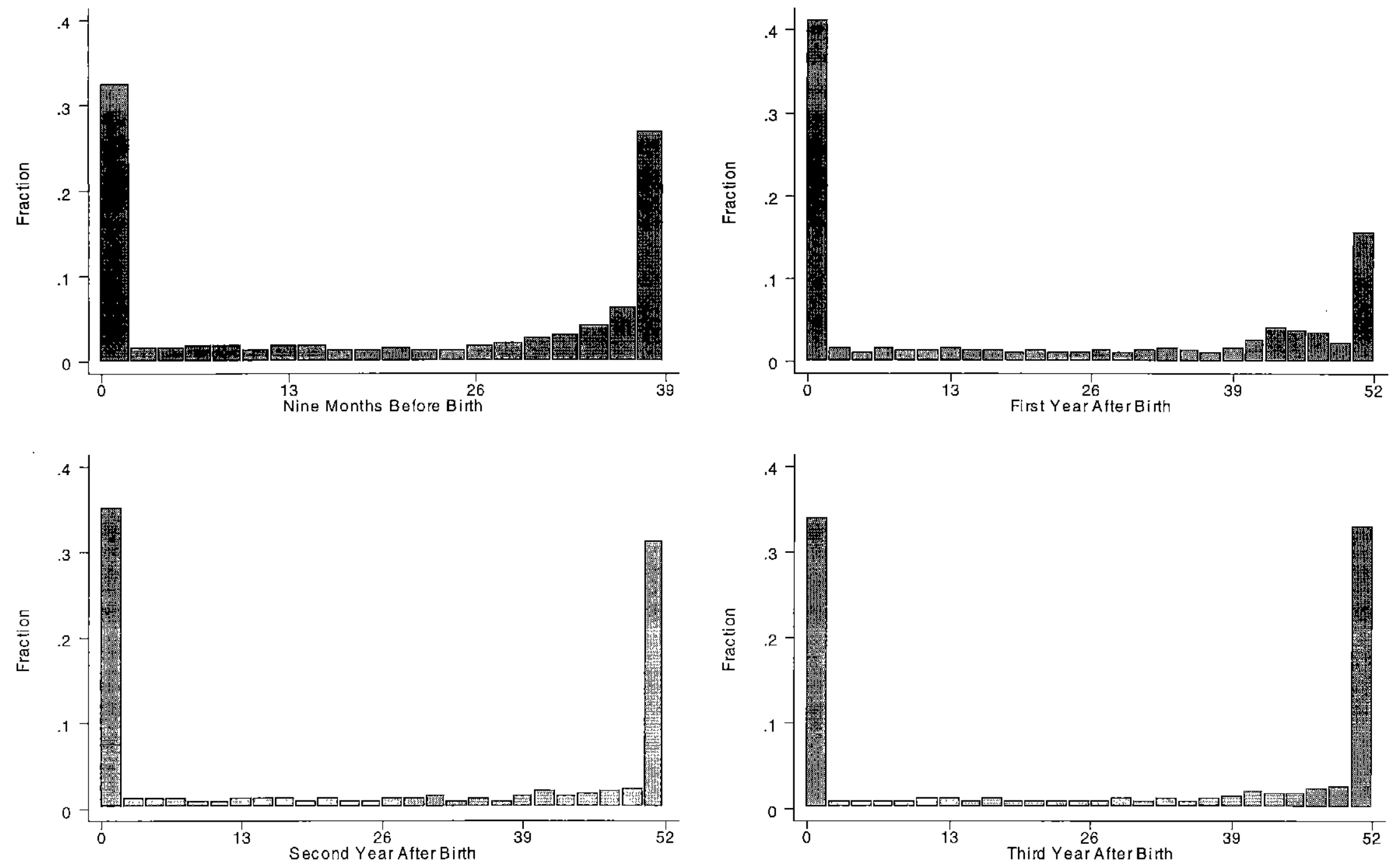
Fig 2: Weekly Work Hours of Mothers Before and After Child Birth
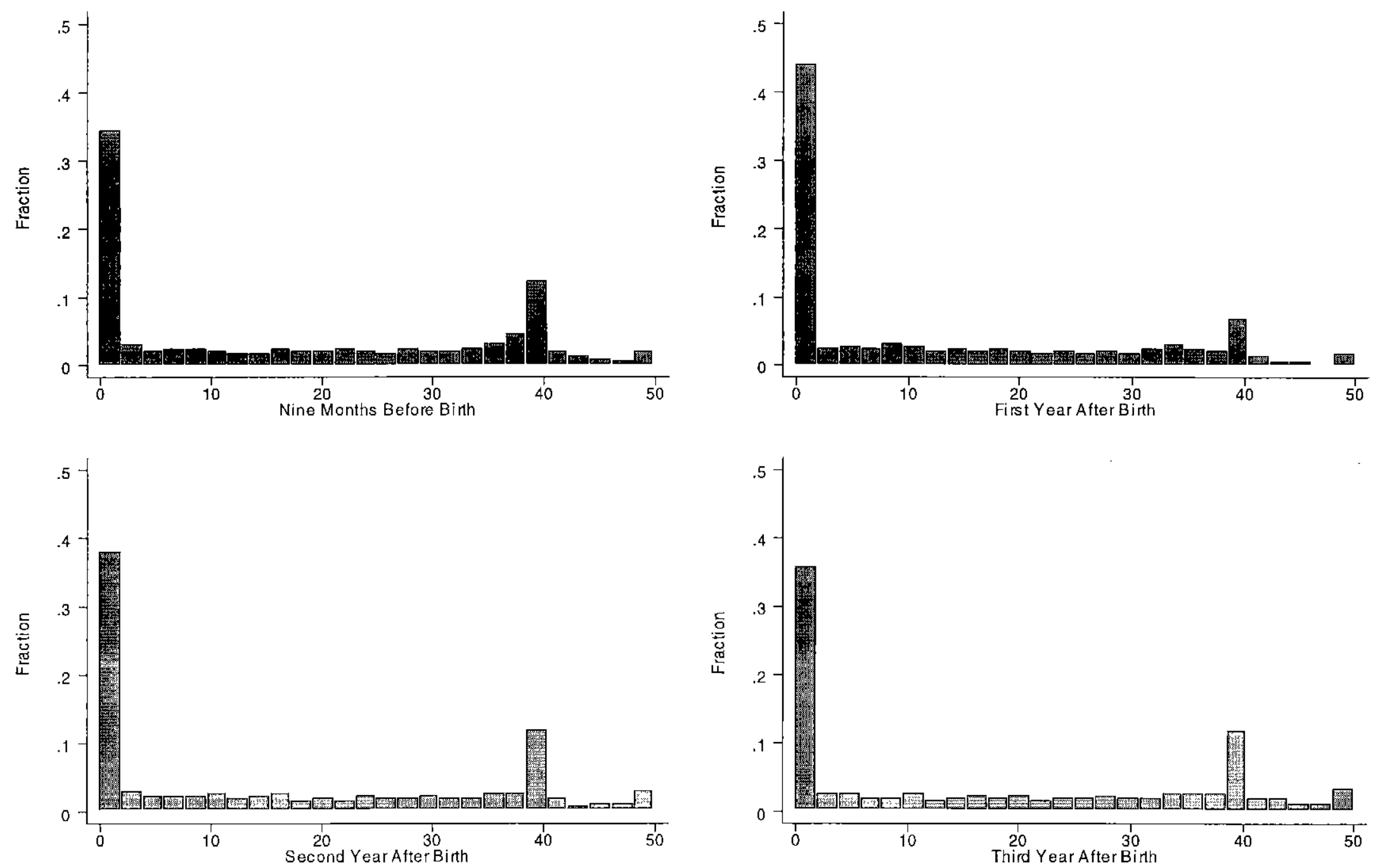
Fig 3: Average Work Hours Of Mothers In Weeks of Employment
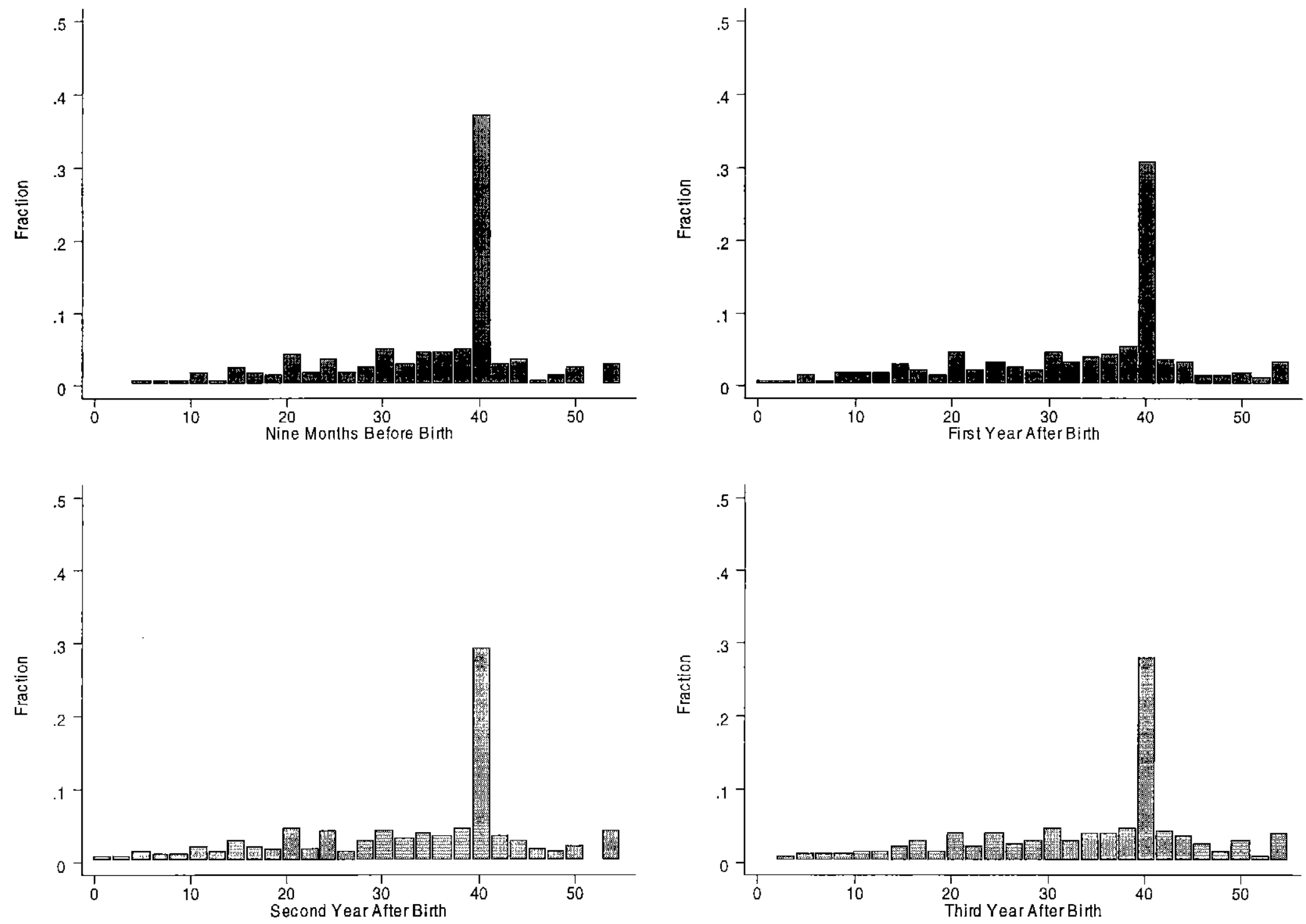
Fig. 4: Employment and Hazard Rates of Pregnant Women By Weeks Before Birth

- Unconditional Probability o Conditional Probability

- Hazard rate $\times 5$

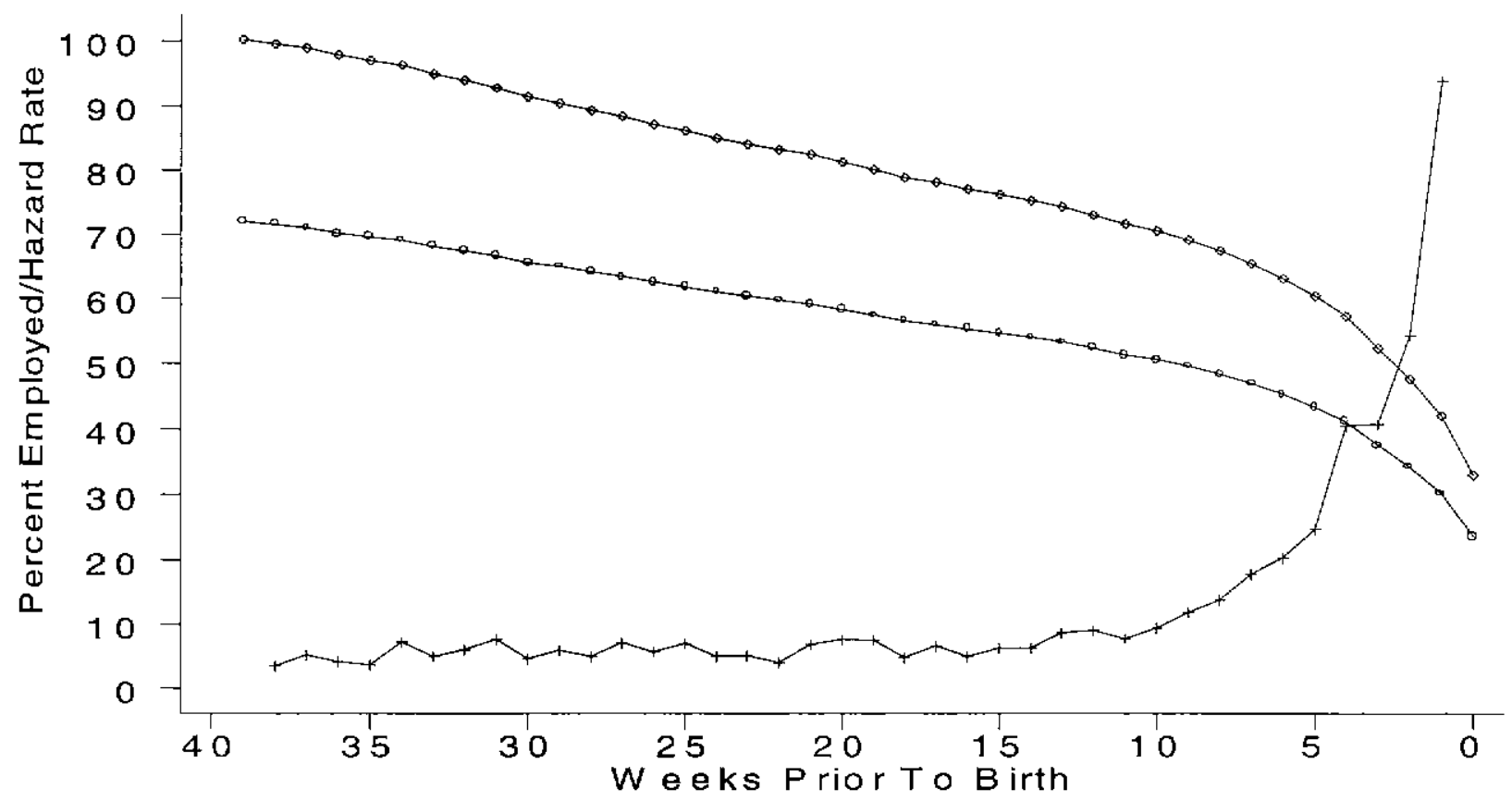

Fig. 5: Reemployment Probabilities and Hazard Rates of Mothers by Child Age (in weeks)

- Unconditional P robability

+ Hazard Rate $\times 10$

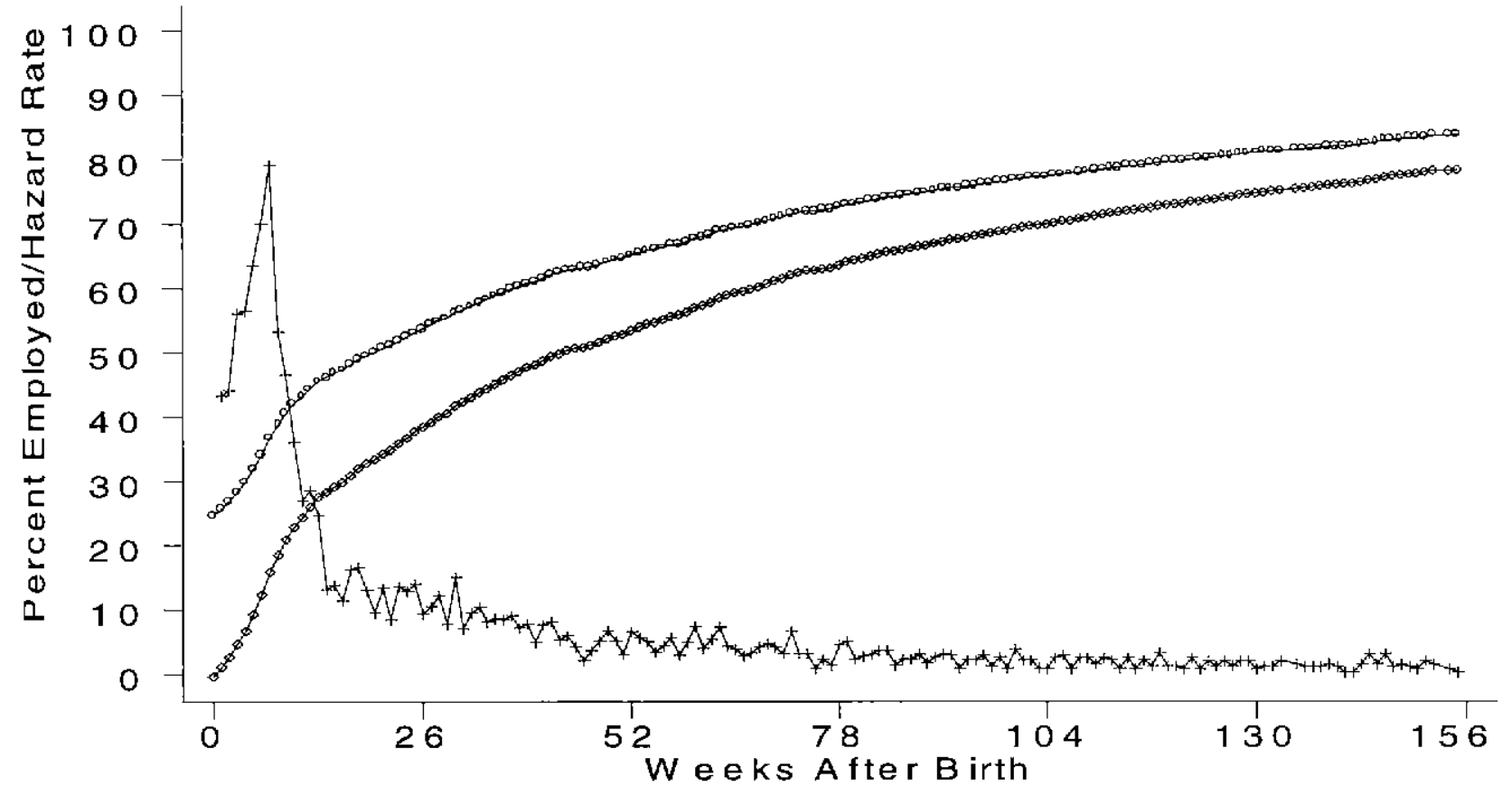


Fig. 6: Weeks and Hours Worked By Fathers
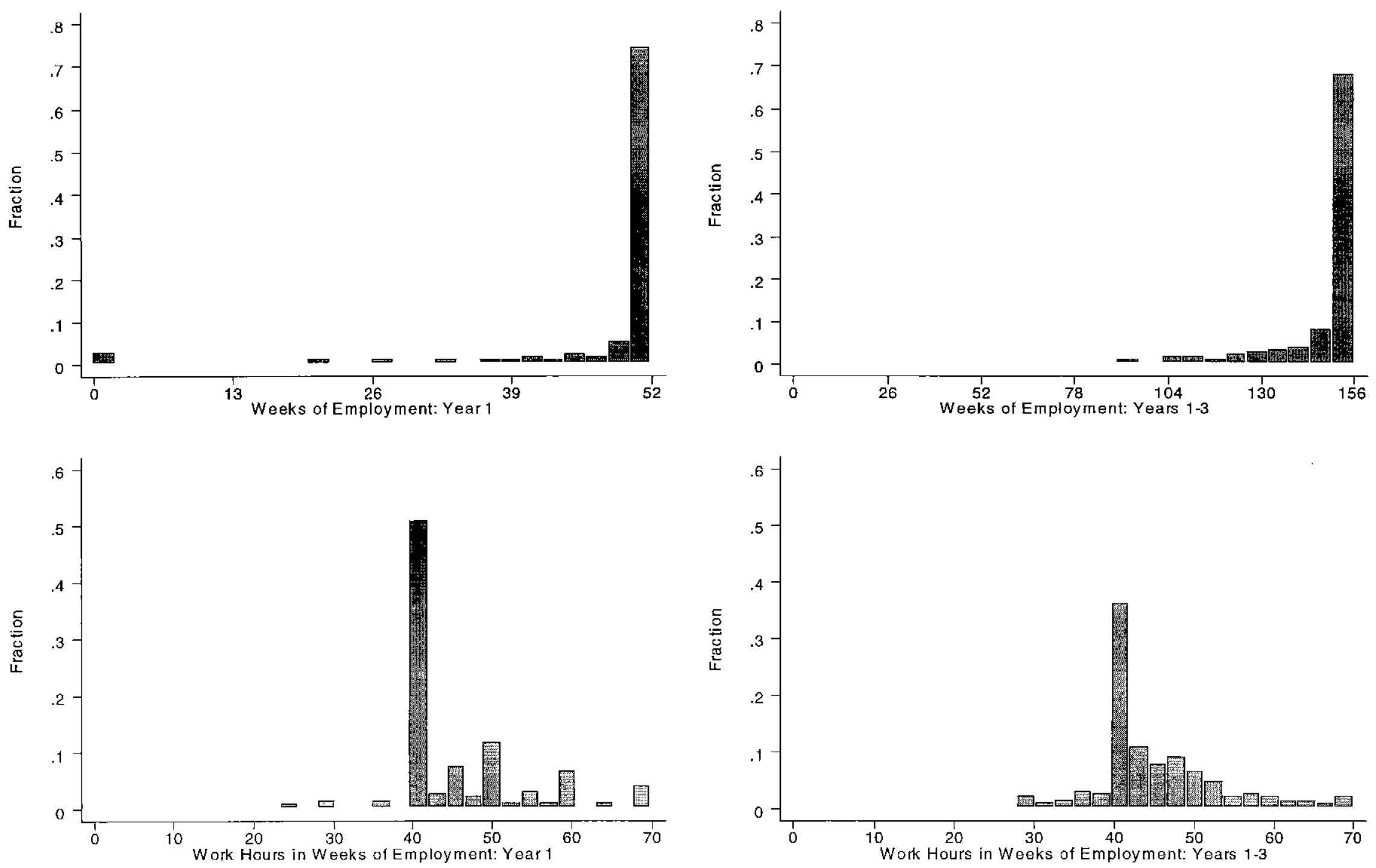